\title{
Characteristics of fog in an aerodrome in a tropical lowland area in northwestern Amazonia
}

\author{
RAFAEL MARTÍNEZ-MANCERA and ASTRID BAQUERO-BERNAL \\ Grupo de Simulación del Sistema Climático Terrestre, Universidad Nacional de Colombia Sede Bogotá, Av. Carrera \\ 30 núm. 45-03, Edificio 476 - Oficina 11, C.P. 111321, Bogotá D.C., Colombia \\ Corresponding author: A. Baquero; email: abaquerobe@unal.edu.co
}

Received: January 22, 2015; accepted: December 18, 2015

\begin{abstract}
RESUMEN
Se muestra el análisis de los reportes meteorológicos aeronáuticos de rutina (METAR, por sus siglas en inglés) generados en el aeródromo "Ernesto Esguerra Cubides" (EEC) (base aérea Tres Esquinas). El aeródromo está localizado en el municipio de Solano en la Amazonia de Colombia. Los reportes cubren el período del 1 de enero de 2009 al 31 de diciembre de 2012, y ayudan a identificar y analizar las características de la ocurrencia de eventos de niebla en el aeródromo EEC. Los resultados muestran que la niebla es un fenómeno meteorológico frecuente en dicho aeródromo. En promedio, uno de cada cinco días del periodo de estudio tiene al menos un reporte de niebla. La niebla es el fenómeno que causa más cierres del aeródromo debido a condiciones meteorológicas $(45.26 \%)$. El alto porcentaje de episodios de niebla con viento en calma (95\%) y su alta ocurrencia entre las 22:00 y 08:00 HL sugieren que la niebla en el aeródromo es básicamente de tipo radiativo. La niebla aparece en todos los meses del año. Adicionalmente, se analizaron tres episodios de niebla densa sobre el aeródromo EEC a partir de METAR y de reportes meteorológicos aeronáuticos especiales (SPECI, por sus siglas en inglés), imágenes del satélite GOES-13, cartas de análisis en superficie de NOAA y radiosondeos realizados en el aeródromo. El análisis de esta información permitió establecer las condiciones meteorológicas en las cuales se presentaron los episodios. Se encontró que cuando el anticiclón del Atlántico del Norte está más alejado del territorio colombiano y la zona de convergencia intertropical está localizada al norte del territorio, se genera subsidencia en los niveles bajo y medio de la atmósfera. Esto inhibe la convección sobre la zona noroccidental de la Amazonia colombiana y favorece la ocurrencia de niebla y neblina en la zona. La subsidencia en el área también está relacionada con actividad convectiva en los departamentos de Guanía, Vaupés y Guaviare. Esto, junto con condiciones de poca nubosidad y viento en calma, favorece el enfriamiento radiativo, de modo que se incrementa la probabilidad de niebla y neblina.
\end{abstract}

\begin{abstract}
An analysis of meteorological terminal aviation routine weather reports (METAR) generated at the "Ernesto Esguerra Cubides" (EEC) aerodrome (Tres Esquinas Airbase) is shown. The aerodrome is located in the municipality of Solano in the Colombian Amazonia. Reports covering the period January 1, 2009 to December 31, 2012 helped to identify and analyze the characteristics of the occurrence of fog events at the EEC aerodrome. The results show that fog is a frequent meteorological phenomenon at the EEC aerodrome: on average, one in five days of the study period had at least one report of fog. At the EEC, fog is the meteorological phenomenon that causes the most weather-related aerodrome closures; it caused $45.26 \%$ of the closures of the EEC aerodrome. The high percentage of episodes of fog with calm wind (95\%) and its high occurrence between 22:00 and 08:00 LT suggest that fog at the EEC aerodrome is basically radiative-type. Fog appears in every month of the year. In addition, three episodes of dense fog over the EEC aerodrome were analyzed from METAR and aviation special weather reports (SPECI), images from the GOES-13 satellite, NOAA surface analysis charts and radio soundings made at the EEC aerodrome. The analysis of this information allowed us to establish the weather conditions in which three fog events were presented.
\end{abstract}


It was found that in times when the North Atlantic anticyclone is farthest from the Colombian territory and the Intertropical Convergence Zone is located north of the territory, subsidence is generated in the lower and middle levels by inhibiting convection over the northwestern part of the Colombian Amazonia and favoring the occurrence of fog or mist in the area. Subsidence over the area is also related to convective activity in the departments of Guainía, Vaupés and Guaviare. This, together with sky conditions with few clouds and calm winds favor radiative cooling, increasing the likelihood of fog and mist.

Keywords: Fog observations, lowland tropical cloud forest, Amazonia, METAR and SPECI reports, aerodrome closures, Colombia, South America.

\section{Introduction}

According to the glossary of the American Meteorological Society (AMS) (http://amsglossary.allenpress. com/glossary), fog is water droplets suspended in the atmosphere in the vicinity of the Earth's surface, reducing visibility. Fog normally occurs at a high relative humidity $(\mathrm{RH})$. Two important variables for aviation are the horizontal visibility and cloud ceiling measured at the surface. The presence of fog negatively affects both variables and adds a significant cost to navigation.

At an aerodrome, the presence of fog (FG) is declared when visibility is $1 \mathrm{~km}$ or less, $\mathrm{RH}$ is above 90\% and observers report fog as a present weather phenomenon. As stated in Eugster (2008), there are two types of fog that can be produced at land. Both of them are named according to the process that formed the fog: radiation fog and advection fog. Radiation fog is very common in areas where cold air can accumulate during the night, or for longer periods in winter, occurring when radiative cooling at the surface reduces air temperature near to the dew point temperature or to a lower temperature. Radiation fog formation is favored when there is a relatively shallow layer of moist air under a dry layer and clear skies. This occurs mainly at night or early morning hours. Advection fog requires a steady wind that moves a fog layer that has formed upwind of a given site, contrasting with radiation fog, which basically implies weak wind conditions or stagnant air masses at the surface.

In a recent comprehensive review, Gultepe et al. (2007) discussed the numerous studies related to various aspects of fog, noting the steady progress made in observing, studying and modeling over the last century, but also highlighting that uncertainties remain in the numerical simulation of fog events, and extensive measurements of fog are needed to better parameterize its physics and develop accurate forecasting systems and retrieval techniques using remote sensing data.

This study focuses on the area of the "Ernesto Esguerra Cubides" (EEC) aerodrome, also known as Tres Esquinas Air Base $\left(00^{\circ} 44^{\prime} \mathrm{N}, 7^{\circ} 13^{\prime}\right.$ W, 178 masl; see Fig. 1). The EEC aerodrome is located $2 \mathrm{~km}$ away from the urban area of Solano, Caquetá, in the northwestern part of the Colombian Amazonia (southwestern Colombia). The EEC aerodrome is located in an area of tropical forest lowland with warm humid climate. According to the Instituto de Hidrología, Meteorología y Estudios Ambientales (Institute of Hydrology, Meteorology and Environmental Studies, IDEAM), this climate is characterized by average temperatures at or above $24{ }^{\circ} \mathrm{C}$ and average rainfall between 3000 and $5000 \mathrm{~mm} \mathrm{yr}^{-1}$ (IDEAM, 2005).

The aerodrome is located on the east bank of the Orteguaza River, near its junction with the Caquetá River, a tributary of the Amazon. According to

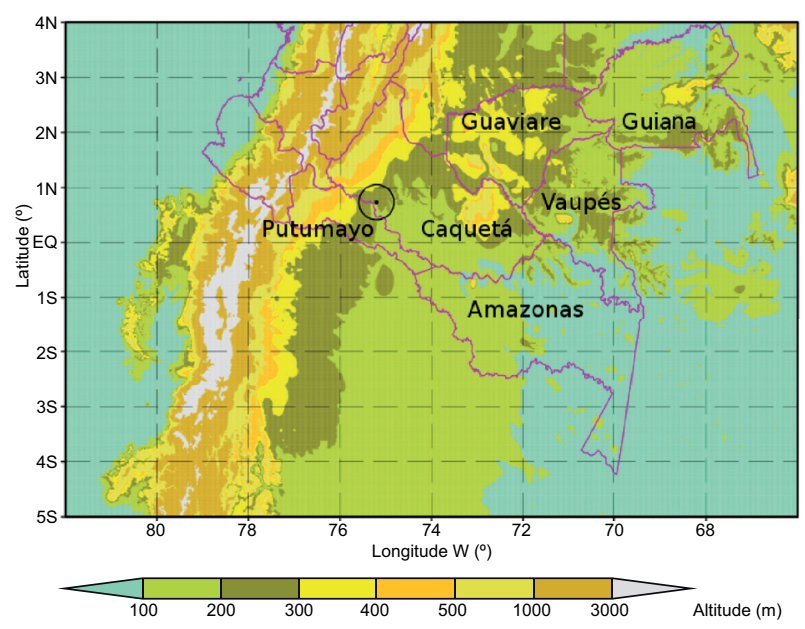

Fig. 1. Political map and topography of the Colombian Amazon catchment basin. The departments that constitute the basin are named. The circle on the map shows the geographical location of the EEC aerodrome. 
SIATAC (2013), the land cover immediately surrounding the aerodrome is classified as a mosaic-type of pasture with natural spaces and clean pasture. A few kilometers from the aerodrome, the land cover-types are fragmented forest pasture and crops, wetlands and high dense forestland (Fig. 2). According to the Historical Land-Cover Change and Land-Use Conversions Global Dataset (Meiyappan and Jain, 2012), the dominant land cover-type for both 2009 and 2010 in the grid cell corresponding to the EEC aerodrome, and in the grid cells corresponding to the whole Colombian Amazonia, is tropical evergreen broadleaf forest. There is no information for the years 2011 and 2012 , but the small changes in land cover from 2009 to 2010 suggest that land cover-types in the
Colombian Amazonia and their area percentages were very similar from 2009 to 2012 .

As stated by Obregón et al. (2014) and references therein, tropical cloud forests are generally associated with mountainous regions and are called "tropical montane cloud forests" (TMCFs), which are widespread in the tropics above 500 masl, usually occurring between 2000 and $3000 \mathrm{~m}$. TMCFs have been recognized for their high biodiversity and as providers of high-quality fresh water, and they generally differ from lowland rain forests in structure and function. Recent studies in tropical lowland forests of French Guiana, however, indicate that cloud forests are not limited to tropical mountain areas but also occur in lowland areas well below 500 masl, with high epiphyte richness resembling TMCFs

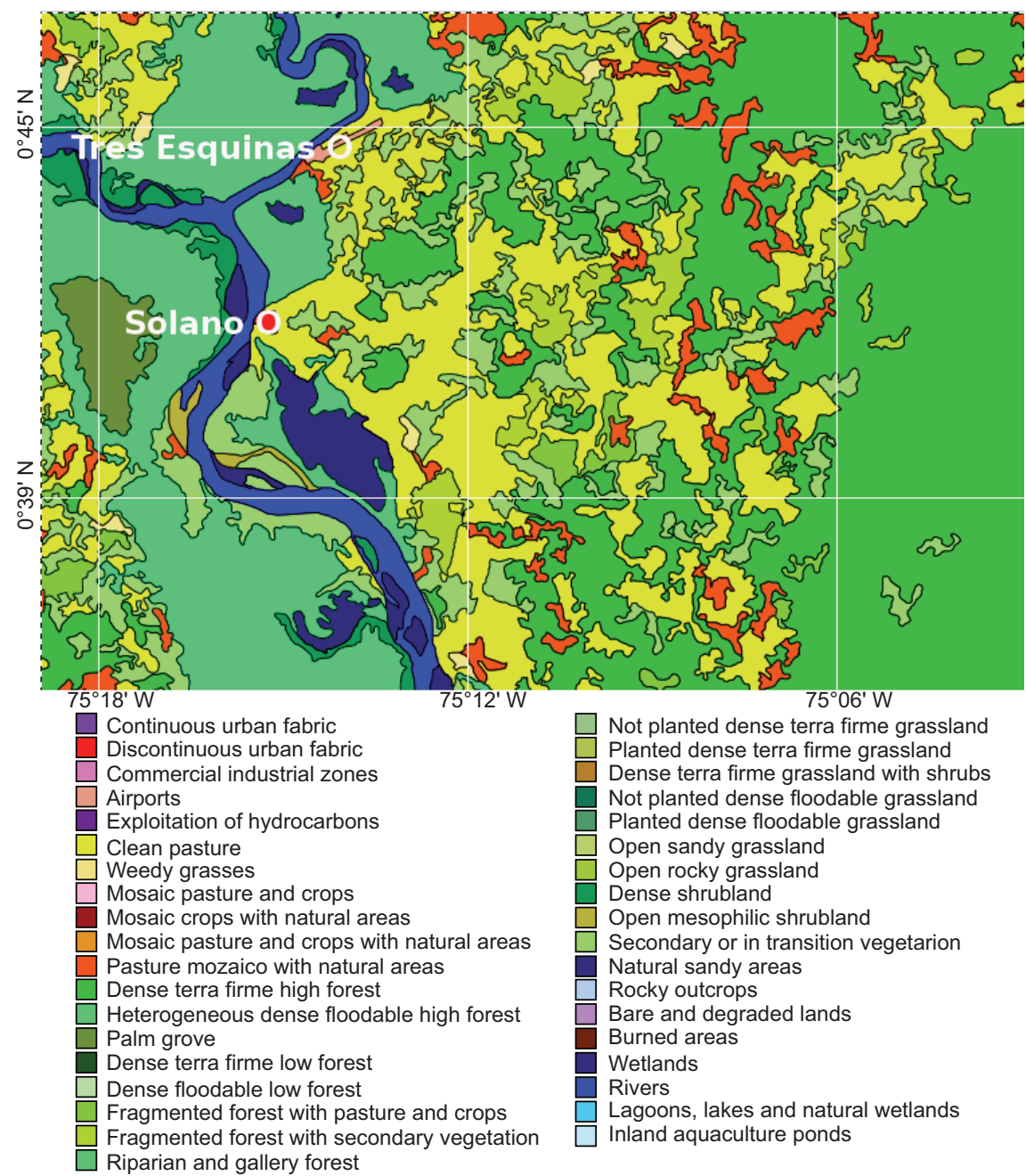

Fig. 2. Land cover map for Tres Esquinas and the surrounding area for 2012. Adapted from SIATAC (2013). 
(Obregón et al., 2011, among others). TMCFs can be characterized by the frequent occurrence of advective clouds touching the ground, which is different from the radiation fog normally occurring at night due to radiation processes in lowland cloud forests (Richter et al., 2013).

Fog formation over tropical lowland forests has hardly been documented in the scientific literature. There are only a few local studies for West Africa (Kamara, 1989), southwestern China (Liu et al., 2008), central Amazonia (De Araújo, 2009; Baars et al., 2012), and eastern Amazonia (Obregón et al., 2011). No studies are available on the formation of fog in the northwestern plains of the Amazon basin, which are located in Colombia. The occurrence of fog over Colombian territory has been addressed for airports such as "José María Córdova" in Rionegro, Antioquia (Aguilar-González and León-Aristizábal, 2004) and the aerodrome "Germán Olano" in Puerto Salgar, Cundinamarca (Jiménez-Sánchez and Zea-Mazo, 2005). These airports are located in urban areas. The purpose of this study is to synthesize the characteristics of fog occurrence in the EEC aerodrome, an airport located in the Amazon lowlands.

One of the main factors driving seasonal variability across northern South America is the Intertropical Convergence Zone (ITCZ), which is the area encircling the Earth near the equator where the southeast and northeast trade winds converge. The ITCZ is characterized by its erratic weather and patterns, with stagnant calms and violent thunderstorms. The location of the ITCZ varies latitudinally during the year. Over land, it moves back and forth across the equator following the sun's zenith point. The displacement of the ITCZ is from south to north in the first half of the calendar year and in the opposite direction in the second half. Over tropical South America the average width of the ITZC fluctuates between 300 and $500 \mathrm{~km}$ (Martínez et al., 2011). Due to the convergent flow, the ITCZ is the zone of maximum cloudiness and rainfall on the continent.

According to León-Aristizabal et al. (2000), in Colombia and neighboring areas, the eastern segment of the Pacific Ocean ITCZ reaches its extreme southern position at $2^{\circ} \mathrm{N}$ between January and February, while in December the segment is further north. However, this extreme position can reach $10^{\circ} \mathrm{S}$ during El Niño events (Horel and Cornejo-Garrido 1986; Goldberg et al. 1988), producing heavy rain in the internal coastal desert of northern Peru. Between December and February, the continental segment of the ITCZ appears fragmented and independent of the Pacific Ocean segment and is located between 5 and $10^{\circ} \mathrm{S}$. Between March and May, the Pacific segment moves northward and its position near the coast is between 2 and $7^{\circ} \mathrm{N}$. At the same time, the continental branch connects to the Atlantic Ocean segment, forming a single system located east of Colombia between $5^{\circ} \mathrm{S}$ and $1^{\circ} \mathrm{N}$, joined through weakly organized convective clusters over the Andean region. During June, July and August, the Pacific Ocean segment changes position in such a way that at the beginning of the trimester it is located at $8^{\circ} \mathrm{N}$ and at the end of the trimester at $10^{\circ} \mathrm{N}$, entering the Caribbean region. Meanwhile the continental segment presents a southwest-northeast inclination over eastern Colombia, moving towards north and passing from the equator to $8^{\circ} \mathrm{N}$. Between September and November, the Pacific segment starts its southward shift and positions are recorded from 11 to $7^{\circ} \mathrm{N}$. Meanwhile the continental segment also begins its journey towards the south, moving from $8^{\circ} \mathrm{N}$ to the equator on the Orinoco and Amazon regions, slowly losing the inclination to parallel the equator. In this case, the two oceanic segments of the ITCZ are connected via convective clusters as well. On their way through the different regions, the ITCZ determines the rainy seasons in Colombia.

Diverse regional and local atmospheric circulation patterns over northern South America and southern Central America interact with the ITCZ and its migration to modify the annual cycle of precipitation (Poveda et al., 2006 and references therein). Among these, there are two low-level jets, one easterly over the Caribbean around $10-12^{\circ} \mathrm{N}$, and the other, the Chocó jet, westerly at about $58^{\circ} \mathrm{N}$ over the Pacific. A third easterly jet is confined to the $600-700 \mathrm{hPa}$ level over South America and the eastern equatorial Pacific. Other mechanisms and atmospheric circulation patterns associated with climatic variability over the region include the dynamics of tropical easterly waves, squall lines over the Amazon basin, the South American low-level jet, and the intra-seasonal variability associated with the activity of the 30-60 day oscillation.

In this study, the occurrence and duration of episodes of fog in the EEC aerodrome are analyzed. An analysis of three cases of dense radiative fog 
(visibility less than $100 \mathrm{~m}$ ) above the EEC aerodrome in three different months of the year is also reported. The aim of this analysis is to establish the weather conditions in which fog events were presented, and to establish these case studies as benchmarks for improving fog models.

Section 2 below describes the data used and fog frequency. Sections 3 and 4 describe the daily cycle and the annual cycle, respectively, associated with fog events at the EEC aerodrome. In sections 5, 6 and 7, three dense radiative fog case studies are described in detail. Finally, conclusions are presented in section 8 .

\section{Data and fog frequency}

\subsection{Data}

As a primary data source we used meteorological terminal aviation routine weather reports (METAR). These are presented at regular intervals, according to protocols established by the aviation authority of each country, which in the case of Colombia is one hour. METAR reports gather information about the presence of significant phenomena and weather variables of most relevance to air navigation, such as visibility, ceiling at lower, medium or high layers, direction and intensity of surface wind, air temperature, dew point, and barometric pressure.

SPECI reports are aviation special weather reports issued when there is significant deterioration or improvement in aerodrome weather conditions, such as the occurrence of severe weather and significant changes in surface visibility, winds and cloud base height. The elements of the SPECI report are similar to those of the METAR report. In sections 3 to 7 we use data from METAR reports related to wind, air temperature, dew point, barometric pressure and the presence of significant phenomena. In sections 5 to 7 we also use data from METAR and SPECI reports related to horizontal visibility and the height of low-and middle-layer clouds. The availability of important meteorological variables for the study of fog in the EEC aerodrome, such as temperature and dew point, is restricted in the data used because automatic weather station installed at the aerodrome operated intermittently due to power failures.

The set of METAR reports we used is for the period from January 1, 2009 to December 31, 2012. The reports are part of the Meteorological Information System database of the Colombian Air
Force (Sistema de Información Meteorológica de la Fuerza Aérea Colombiana, SIMFAC). In sections 3 and 4, we show the hour of the day without minutes since all METAR times correspond to o'clock hours. In this study we only consider METAR reports in which at least wind direction and wind speed were recorded. Table I shows the total number of available reports with wind measurement for each month and hour within the study period.

\subsection{Fog frequency}

Fog is a frequent meteorological phenomenon at the EEC aerodrome. Table II shows that, on average, one out of every five days of the study period had at least one report of fog. Table III shows that just over $70 \%$ of the total number of hours of closure of the EEC aerodrome by atmospheric conditions (APCLM) were due to foggy weather events (FG, $\mathrm{MIFG}+\mathrm{PRFG}+\mathrm{FZFG}+\mathrm{VCFG}, \mathrm{BCFG}$ ) and mist (BR). Fog was the phenomenon that caused the most aerodrome closure events, with $45.26 \%$ of all cases.

For the reporting period, various types of precipitation were recorded: drizzle accompanied with rain and showers in the vicinity (i.e., at a distance of $16 \mathrm{~km}$ or less), drizzle, rain, rain storms, rain and hail storms, and rain showers. There were 960 days with at least one report of precipitation and 285 days with at least one report of fog. Precipitation in the afternoon can pre-condition the environment and make radiation fog more likely, because it can both moisten the air through evaporation and cool the environment through evaporative cooling. If the late afternoon air is moistened or cooled (or both) by precipitation, then it may be very close to $100 \% \mathrm{RH}$ at sunset. Table IV shows that $\approx 70 \%$ of the days with at least one fog report were preceded by at least one episode of precipitation on the afternoon of the previous day. This suggests that precipitation is a precursor of fog at the EEC aerodrome.

\section{Average values for the METAR reports}

\subsection{Daily cycle}

Figure 3a shows the relative frequency of occurrence of different types of wind according to the time of day and their direction: calm wind, variable wind, prevailing north wind $(\mathrm{N}$; winds between 315 and $\left.45^{\circ}\right)$, east wind $\left(E\right.$; winds between 45 and $135^{\circ}$ ), south wind (S; winds between 135 and $225^{\circ}$ ) and west wind $\left(\mathrm{W} ; 225\right.$ and $\left.315^{\circ}\right)$. The frequency is calculated 
Table I. Number of METAR reports per hour and per month with wind measurement available for the period January 1, 2009 to December 31, 2012.

\begin{tabular}{|c|c|c|c|c|c|}
\hline $\begin{array}{c}\text { Hour } \\
\text { (LT) }\end{array}$ & $\begin{array}{l}\text { Number of } \\
\text { METAR reports } \\
\text { with wind }\end{array}$ & $\begin{array}{c}\text { Number of } \\
\text { METAR reports } \\
\text { with wind and fog }\end{array}$ & Month & $\begin{array}{l}\text { Number of } \\
\text { METAR reports } \\
\text { with wind }\end{array}$ & $\begin{array}{l}\text { Number of } \\
\text { METAR reports } \\
\text { with wind and fog }\end{array}$ \\
\hline 19 & 1279 & 1 & 1 & 2489 & 42 \\
\hline 20 & 1295 & 2 & 2 & 2271 & 59 \\
\hline 21 & 1285 & 9 & 3 & 2348 & 52 \\
\hline 22 & 1291 & 13 & 4 & 2509 & 99 \\
\hline 23 & 1283 & 32 & 5 & 2673 & 62 \\
\hline 1 & 1275 & 57 & 6 & 2633 & 63 \\
\hline 2 & 1262 & 83 & 7 & 2755 & 109 \\
\hline 3 & 1251 & 85 & 8 & 2632 & 71 \\
\hline 4 & 1255 & 113 & 9 & 2541 & 79 \\
\hline 5 & 1283 & 137 & 10 & 2772 & 80 \\
\hline 6 & 1260 & 175 & 11 & 2558 & 73 \\
\hline 7 & 1314 & 136 & 12 & 2763 & 93 \\
\hline 8 & 1349 & 30 & & & \\
\hline 9 & 1356 & 6 & Total & 30944 & 882 \\
\hline 10 & 1351 & 0 & & & \\
\hline 11 & 1336 & 0 & & & \\
\hline 12 & 1297 & 0 & & & \\
\hline 13 & 1311 & 1 & & & \\
\hline 14 & 1262 & 0 & & & \\
\hline 15 & 1322 & 1 & & & \\
\hline 16 & 1315 & 0 & & & \\
\hline 17 & 1302 & 0 & & & \\
\hline 18 & 1249 & 1 & & & \\
\hline Total & 30944 & 882 & & & \\
\hline
\end{tabular}

Table II. Number of days with at least one report of fog in the period from January 1, 2009, to December 31, 2012.

\begin{tabular}{lccccc}
\hline Year & 2009 & 2010 & 2011 & 2012 & Average \\
\hline Number of days & 55 & 94 & 75 & 61 & 71.25
\end{tabular}

from the total number of METAR reports for each hour of the day (values in Table I, second column). For example, at 19:00 LT there were 1161 records and 912 of those recorded calm winds, so for that hour and kind of wind the corresponding frequency of occurrence was $78.55 \%$.

In the course of the day, calm winds predominate in the EEC aerodrome. The frequency of calm winds varied between minimum and maximum frequencies of 41.30\% at 15:00 LT and 88.61\% at 05:00 LT (Fig. 3a). Less frequently, N, E, S, W, and variable winds also occurred. The frequencies of occurrence of these winds varied between $0.00 \%$ for variable winds at 08:00, 11:00, 12:00 and 18:00 LT, and $18.46 \%$ for $\mathrm{W}$ wind at 15:00 LT.
Wind speed (WS) at the EEC aerodrome was low on average (Fig. 3b). For the period of study, WS showed a marked diurnal cycle with maximum values between 13:00 and 15:00 LT, ranging from 3.18 to $3.21 \mathrm{~ms}^{-1}$ and a minimum value at 05:00 LT of $1.93 \mathrm{~ms}^{-1}$. Similarly, atmospheric pressure showed a distinctive daily cycle, with an absolute minimum of $985.88 \mathrm{mb}$ at 17:00 LT, a relative maximum of 988.72 mbat23:00LT, a relative minimumof $988.38 \mathrm{mb}$ at 03:00 LT and an absolute maximum value of 990.38 $\mathrm{mb}$ at 10:00 LT.

Air temperature, dew point and relative humidity showed a marked diurnal cycle (Fig. 3c). For air temperature (dew point), the minimum value of $20.18^{\circ} \mathrm{C}\left(19.62^{\circ} \mathrm{C}\right)$ occurred at 06:00 LT and the maximum value of $28.27^{\circ} \mathrm{C}\left(22.18^{\circ} \mathrm{C}\right)$ occurred at 14:00 LT. Air temperature exceeded the dew point by $0.56{ }^{\circ} \mathrm{C}$ at $06: 00 \mathrm{LT}$ and $6.22^{\circ} \mathrm{C}$ at $14: 00$ LT. For relative temperature, a minimum value of $70.74 \%$ occurred at 15:00 LT and a maximum value of $96.75 \%$ occurred at 06:00 LT. 
Table III. Number of METAR reports reporting the closure of the EEC aerodrome due to weather conditions. Intensity qualifiers are heavy $(+)$ and light $(-)$. Moderate intensity has no qualifier.

\begin{tabular}{llcc}
\hline Phenomenon & \multicolumn{1}{c}{$\begin{array}{c}\text { Acronyms used in } \\
\text { METAR reports }\end{array}$} & $\begin{array}{c}\text { Number of } \\
\text { METAR reports }\end{array}$ & $\begin{array}{c}\text { Percentage of METAR } \\
(\%) \text { reports }\end{array}$ \\
\hline Fog & FG & 693 & 45.26 \\
Rain & (+RA)+(-RA)+RA & 246 & 16.07 \\
Mist & BR & 152 & 9.93 \\
Shallow fog + partial fog + freezing* & MIFG + PRFG + FZFG & & \\
Fog + fog in the vicinity & VCFG & 151 & 9.86 \\
Patches of fog & BCFG & 127 & 8.30 \\
Drizzle & (+DZ) + (-DZ) + DZ & 94 & 6.14 \\
Other phenomena & & 69 & 4.44 \\
& Total & 1532 & 100 \\
\hline
\end{tabular}

*These phenomena were not counted as fog because their visibility and RH values do not necessarily fall within the definition of fog.

Table IV. Number of days with at least one report of fog preceded by at least one episode of precipitation on the previous day under several precipitation conditions.

\begin{tabular}{lcc}
\hline Precipitation condition & $\begin{array}{c}\text { Number of days with at } \\
\text { least one report of fog }\end{array}$ & $\begin{array}{c}\text { Percentage (\%) of days } \\
\text { with at least one report } \\
\text { of fog }\end{array}$ \\
\hline $\begin{array}{l}\text { None } \\
\text { Previous day at all times of the day (i.e., between }\end{array}$ & 285 & 100.00 \\
$\begin{array}{l}\text { 19:00 LT on day }-2 \text { and 18:00 LT on day }-1) \\
\text { Previous day at every hour after sunrise (i.e., between }\end{array}$ & 229 & 80.35 \\
07:00 LT on day -1 and 18:00 LT on day -1$)$ & 208 & 72.98 \\
$\begin{array}{l}\text { Previous day at every hour after noon (i.e., between } \\
\text { 12:00 LT on day }-1 \text { and 18:00 LT on day }-1)\end{array}$ & 197 & 69.12 \\
\hline
\end{tabular}

\subsection{Annual cycle}

Figure 4 a shows the frequency of occurrence of different types of wind in the METAR reports according to direction and the month of the year. The frequency is calculated with respect to the total number of METAR reports for each month year (values in Table I, column 5). Calm winds predominate in the EEC aerodrome during the year. The frequency of calm winds varied between minimum and maximum frequencies of $61 \%$ in September and 78\% in February. Less frequently, variable wind and winds with $\mathrm{N}, \mathrm{E}, \mathrm{S}$, and $\mathrm{W}$ directions also occurred. The maximum frequencies of occurrence of these winds varied between minimum and maximum frequencies of $0.7 \%$ for variable wind in May and $15.3 \%$ for $\mathrm{E}$ wind in December.

Wind speed (WS) in the EEC aerodrome fluctuated around $2.72 \mathrm{~ms}^{-1}$ and varied between minimum and maximum values of $2.39 \mathrm{~ms}^{-1}$ in September and $3.21 \mathrm{~ms}^{-1}$ in January (Fig. 4b). WS at the EEC aerodrome on average was low, which shows a monomodal annual cycle. Similarly, atmospheric pressure shows a monomodal distinctive annual cycle with maximum values from June to August between 990.2 and $990.3 \mathrm{mb}$, and the lowest values from November to February, between 986.3 and $986.8 \mathrm{mb}$.

Both air temperature and dew point also show an annual cycle of bimodal type and are very similar to each other (Fig. 4c). For air temperature (dew point), there was an absolute minimum of $22.19{ }^{\circ} \mathrm{C}$ $\left(19.71^{\circ} \mathrm{C}\right.$ ) in June, with maximum values during November and December between $25.02{ }^{\circ} \mathrm{C}$ and $25.03{ }^{\circ} \mathrm{C}\left(22.08{ }^{\circ} \mathrm{C}\right.$ and $\left.13{ }^{\circ} \mathrm{C}\right)$, a relative minimum of $23.25^{\circ} \mathrm{C}\left(20.22{ }^{\circ} \mathrm{C}\right)$ in February, and a relative maximum of $23.83{ }^{\circ} \mathrm{C}\left(19.71^{\circ} \mathrm{C}\right)$ in March. Air temperature was above the dew point in all months; 

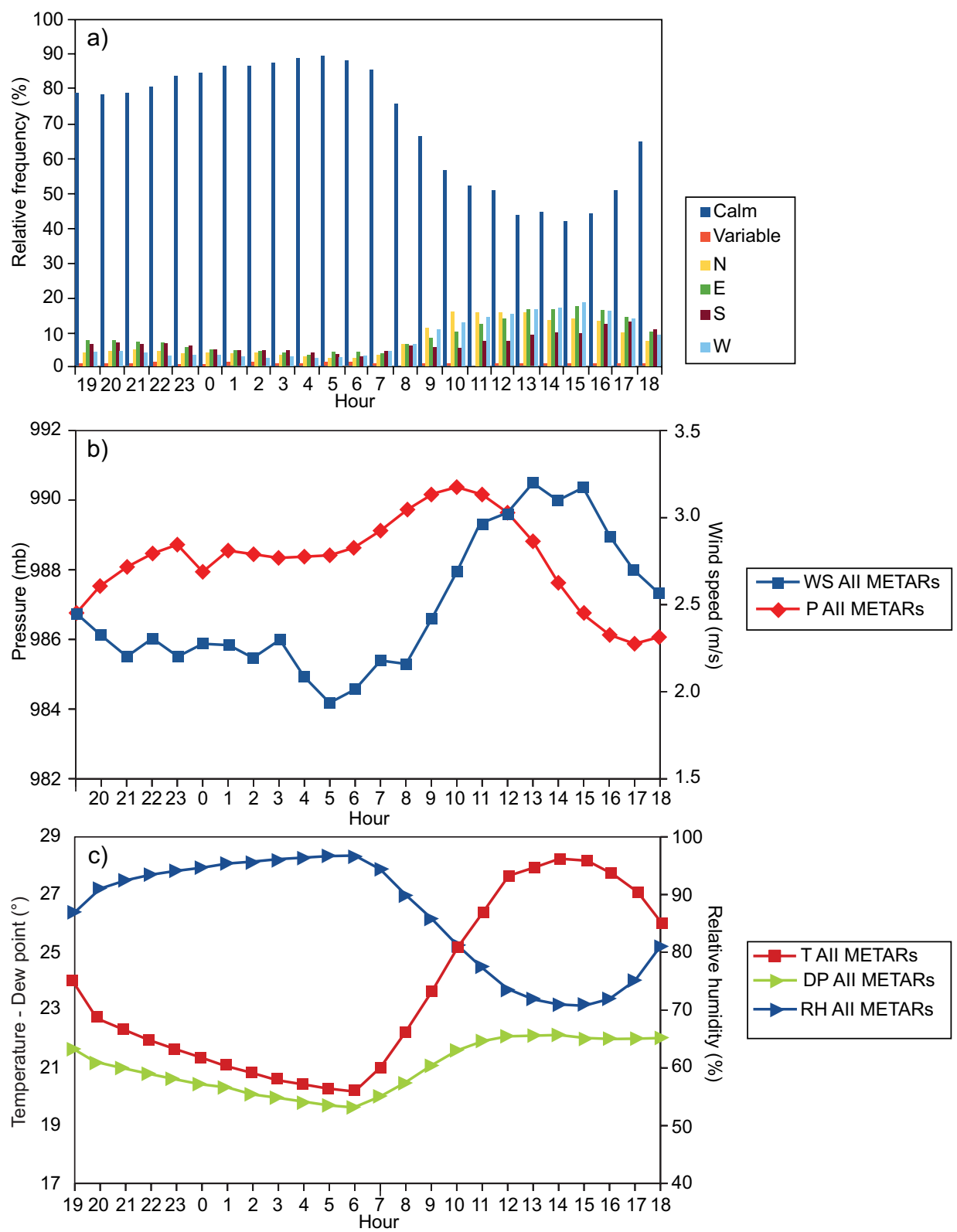

Fig. 3. Frequency of occurrence and average values of several variables according to the time of day listed in METAR reports for the period January 1, 2009, to December 31, 2012. (a) Frequency of occurrence of different types of wind according to the direction. (b) Average values of pressure (P) and wind speed (WS). (c) Average values of air temperature (T), dew point temperature (DP) and relative humidity (RH). In (b) ([c]) the vertical axis to the left corresponds to pressure (temperature and dew point) and the values on the upright axis to the right correspond to wind speed (relative humidity).

in July it was $2.4{ }^{\circ} \mathrm{C}$ and in February $3.5^{\circ} \mathrm{C}$ above the dew point. With regard to $\mathrm{RH}$, the annual mean was $86.06 \%$. RH values from April to August (October to January and March) were above (below) the annual mean.

\section{Average values for METAR reports with fog registration}

4.1 Daily cycle

Figure 5 shows the hours in which more METAR reports of fog were produced at the EEC 

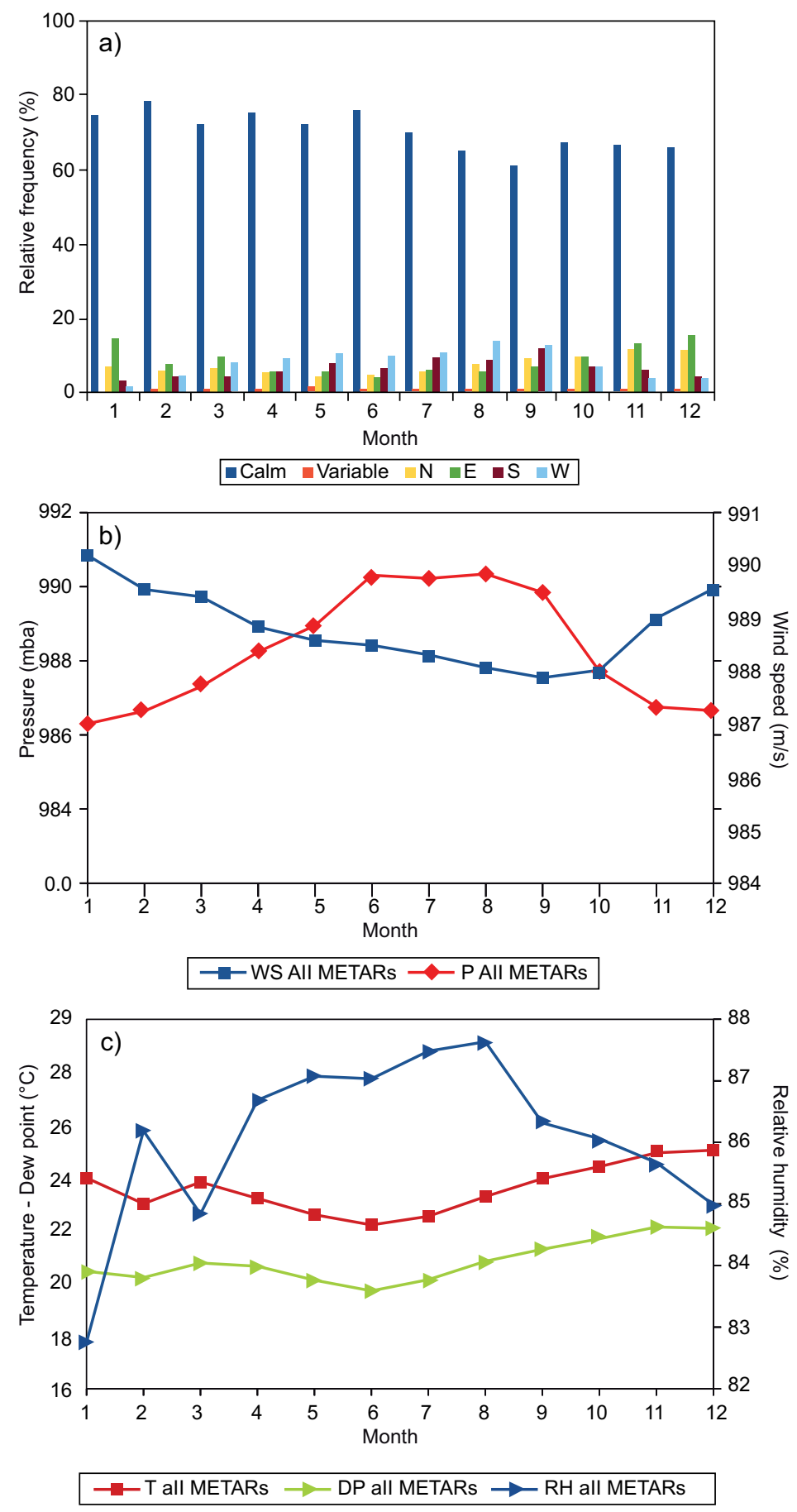

Fig. 4. Frequency of occurrence and average values of several variables according to the months of the year listed in METAR reports for the period January 1, 2009, to December 31, 2012. (a), (b) and (c), as in Figure 3. Vertical axes to the left and right in (b) ([c]), also as in Figure 3.

aerodrome, i.e. between 22:00 and 09:00 LT, with a maximum at 06:00 LT. Among these hours, $99.3 \%$ of the reports with fog registration occurred, 876 of the 882 METAR reports with fog in the period of study. A total of $95 \%$ of the reports with fog (836) recorded calm wind (winds below $0.5 \mathrm{~ms}^{-1}$ ), $4.5 \%$ (42) recorded wind intensity between 1.0 and $2.6 \mathrm{~ms}^{-1}$ and only $0.5 \%$ (four) of the METAR reports with fog recorded wind with intensity between $3.1-4.1 \mathrm{~ms}^{-1}$.

According to Tardif and Rasmussen (2007), fog can be defined as precipitation fog if there is precipitation within one hour before the fog onset. From the 882 METAR reports with fog, only 11 were preceded 


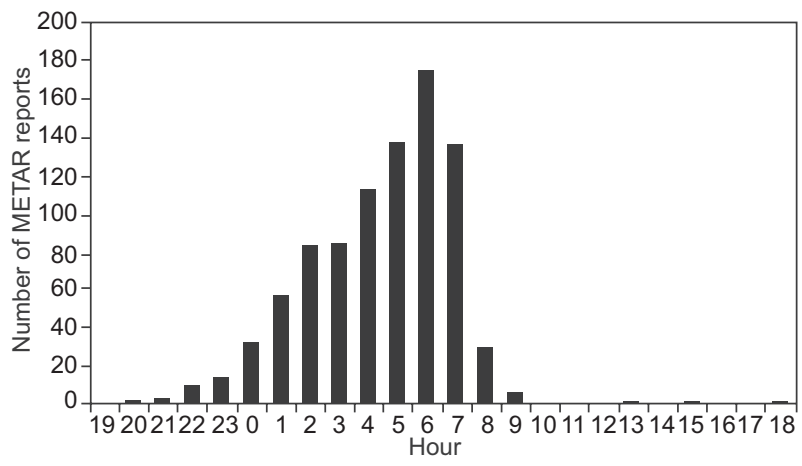

Fig. 5. Number of METAR reports for the period January 1, 2009, to December 31, 2012, with registration of fog according to the time of day.

by a METAR report with precipitation. Thus, from the total METAR reports with fog, only $1.25 \%$ corresponds to precipitation-type fog events.

In this section, the mean values for the variables in the METAR reports with fog are calculated. To avoid the calculation of both frequency of occurrence and average values from one or two data points, the values are obtained from METAR reports between 22:00 and 09:00 LT. Figures 6a-c show the obtained values.

Figure 6a shows the frequency of occurrence of different types of wind according to their direction in the presence of fog. The frequency is calculated from the total number of METAR reports with fog registration for each time of the day (values in Table I, column 3, and in Fig. 5). For example, at 21:00 LT there were nine records with fog and seven of those corresponded to calm wind, so for that time and that kind of wind the corresponding occurrence frequency is $77.78 \%$. In the presence of fog, calm winds predominate in the daily cycle at the EEC aerodrome. The frequency of calm wind was between $77.78 \%$ at $22: 00$ LT and $98.25 \%$ at 01:00 LT (Fig. 6a). Although less frequently, winds with directions $\mathrm{N}, \mathrm{E}, \mathrm{S}$, and $\mathrm{W}$ also occurred. The maximum frequencies of occurrence of these winds were between $3.33 \%$ for $\mathrm{W}$ wind at 08:00 LT and $22.22 \%$ for $\mathrm{S}$ wind at 22:00 LT. There were no occurrences of simultaneous recordings of variable wind and fog. Thus, compared with those frequencies calculated for all METAR reports, in the presence of fog the probability that wind is calm is even greater. There were only frequencies above $15 \%$ for $\mathrm{S}$ winds at 09:00 and 22:00 LT. These hours had low amounts of fog reports (see Fig. 5).
The lower WS values occurred between 19:00 and 09:00 LT (Figs. 3b and 6b). Within this period of time, most fog occurrences were registered between 22:00 and 08:00 LT (Fig. 5). This means that fog occurred preferentially at night and in the morning (between 22:00 and 08:00 LT), when lower WS values were produced. In the presence of fog, WS at the EEC aerodrome fluctuated between $1.5 \mathrm{~ms}^{-1}$ at 07:00 LT and $2.57 \mathrm{~ms}^{-1}$ at 00:00 LT. WS values in the presence of fog between 03:00 and 09:00 LT were lower than values calculated at the same hours for all reports. Moreover, the daily cycle of pressure in the presence of fog is very similar to that obtained when all the METAR reports are taken into account and presents slightly higher values between 01:00 and 22:00 LT. Between 22:00 and 09:00 LT, pressure was relatively high compared with the period between 18:00 and 21:00 LT.

For WS, the lowest values of air temperature and dew point occurred between 08:00 and 19:00 LT (Figs. 3c and 6c). As might be expected in the presence of fog, air temperature and dew point had very similar values (Fig. 6c). The difference between these two temperatures is between $0{ }^{\circ} \mathrm{C}$ at 22:00 LT and $0.61{ }^{\circ} \mathrm{C}$ at 08:00 LT. Moreover, the maximum difference between air temperatures (dew point) calculated for all reports and those calculated for fog reports occurred at 09:00 LT $\left(5.42{ }^{\circ} \mathrm{C}\left[3.09{ }^{\circ} \mathrm{C}\right]\right)$. For $\mathrm{RH}$, values fluctuated between 96.41 and $100.00 \%$. We conclude that the prevailing type of fog in the EEC aerodrome is radiative-type, because it occurs at night and the early hours of the morning (when WS, air temperature and dew point are low), and it dissipates quickly, in most cases before 09:00 LT. In sections 5 to 7 three case studies are shown in which the mechanisms that favor the occurrence of fog in the EEC aerodrome are analyzed.

\subsection{Annual cycle}

Figure 7 shows the number of days with presence of fog by month and the duration of each event (one METAR report with fog or a consecutive number of METAR reports with fog is a fog event). Fog occurred during every month of the year at the EEC aerodrome. The events had a duration ranging from less than one hour to 11-12 hours. Figure 8 shows the number of days with fog episodes by year and the event duration. This figure shows that the number of days decreases with longer episodes. Days with 

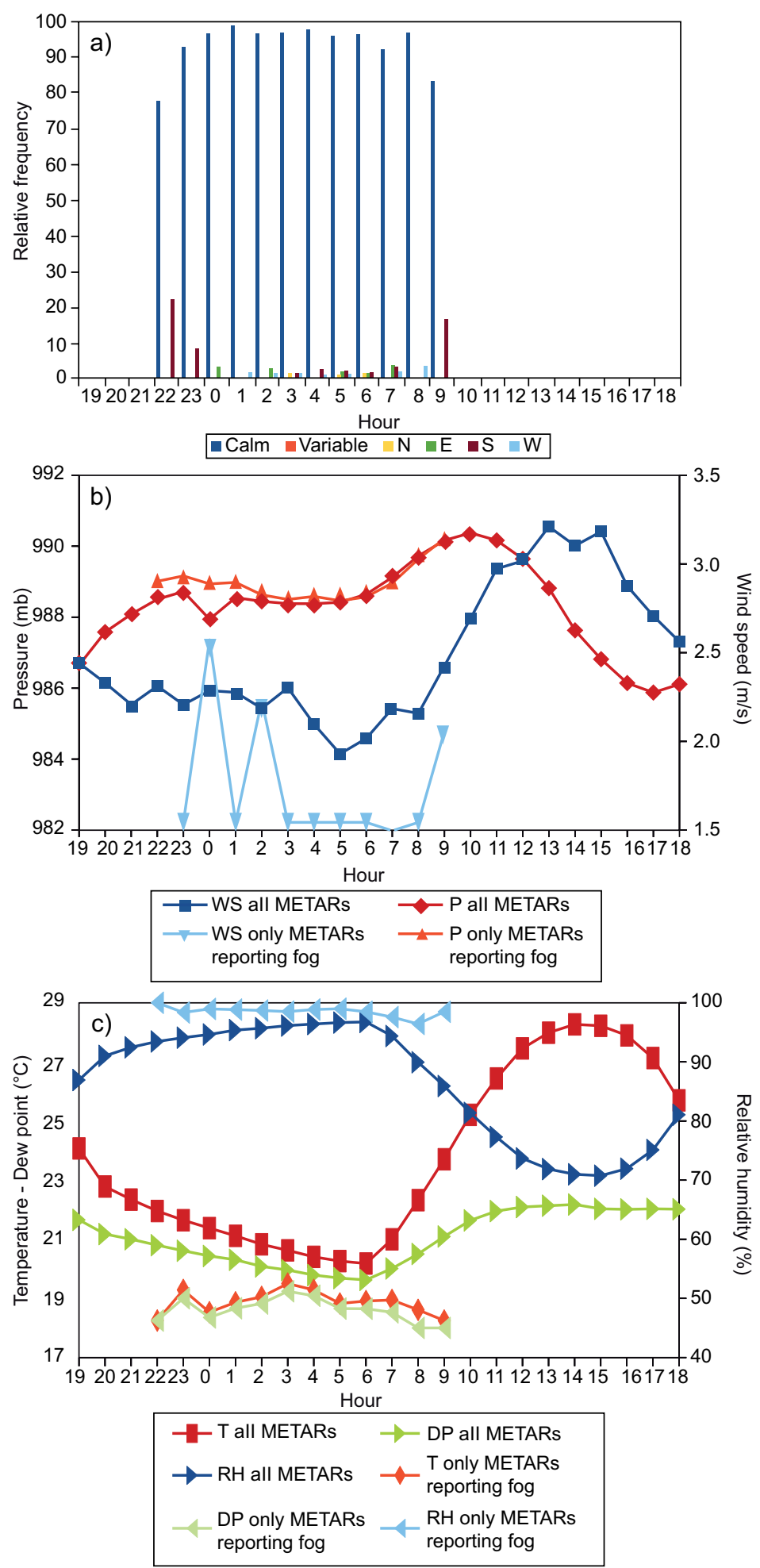

Fig. 6. Frequency of occurrence and average values of several variables according to the time of day for METAR reports with fog registration, for the period January 1, 2009 to December 31, 2012. (a), (b) and (c), as in Figure 3. Vertical axes to the left and right in (b) ([c]), also as in Figure 3. Curves in Figure 3 (for the total of METAR reports) were repeated for clarity.

episodes lasting less than one hour or days with episodes between one and two hours were the most common, and least frequent were episodes lasting eight or more hours. The four longest events (8-9,
9-10, and 11-12 h) were recorded in 2010 and 2011, which correspond to La Niña years.

Figure 9a shows the frequency of occurrence of different types of wind according to both their 


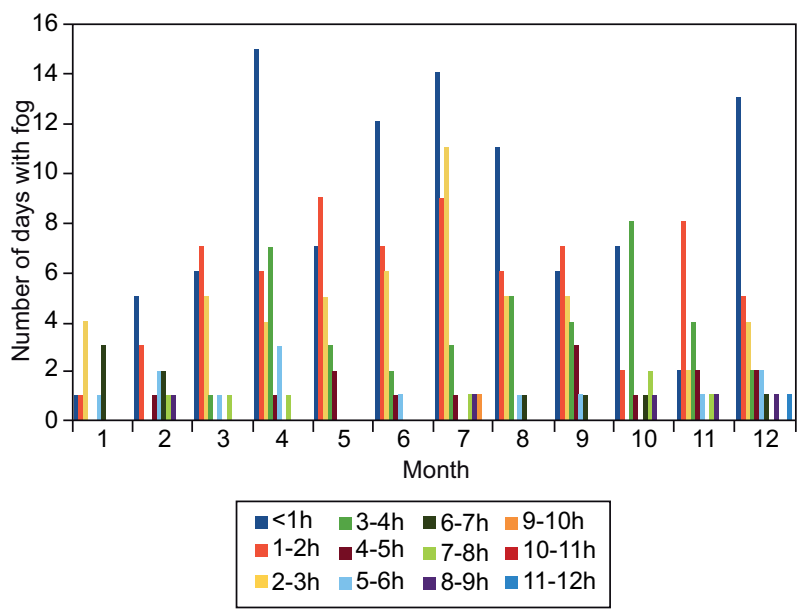

Fig. 7. Number of days with fog presence according to the month and duration of fog events for the period January 1 , 2009, to December 31, 2012.

direction and month when fog is present. The frequency is calculated with respect to the total number of METAR reports with registration of fog for each month of the year (values in Table I, column 6). Calm winds predominate in the annual cycle at the EEC aerodrome in the presence of fog. The frequency of calm winds was between $87.34 \%$ in September and $100 \%$ in February.

Although in smaller proportion, N, E, S, and W also occurred. The maximum frequencies of occurrence of these winds were between $2.74 \%$ for $\mathrm{W}$ in November and $11.39 \%$ for $\mathrm{S}$ in September. Fog with S wind is the result of three events: one in 2012 with five METAR reports, and two in 2009 with one and three reports. There were no occurrences with simultaneous recordings of variable wind and fog. Thus, as in the analysis of the diurnal cycle, the probability that wind was calm was greater when there was fog compared to METAR reports overall.

In the presence of fog, WS at the EEC aerodrome ranged from $1.03 \mathrm{~ms}^{-1}$ in October to $3.09 \mathrm{~ms}^{-1}$ in June (Fig. 9b). In every month except June, WS values in the presence of fog were lower than the values calculated from all reports. Moreover, the annual cycle of pressure in the presence of fog is very similar to that obtained when all the METAR reports are taken into account but presented slightly higher values between October and February. In January (February) the pressure in the presence of fog was $1.8 \mathrm{mb}(1.3 \mathrm{mb})$ above the pressure calculated from all reports. As shown in Figures $4 c$ and $9 c$, minimum pressure values were recorded in January and February. On the other hand, air temperature and the dew point had very similar values, as expected in the presence of fog (Fig. 9c). RH fluctuated between 96.18 and 99.85\%.

There were differences between monthly averages of atmospheric pressure obtained with all METAR reports and monthly averages obtained only with reports that record fog. This can be seen when monthly averages of pressure calculated only for the hours in which fog occurrence is more likely at EEC (i.e., between 22:00 and 09:00 LT [P22-9, see yellow line in Fig. 9b]) are taken into account instead of all hourly METAR reports. In this case, pressure in the presence

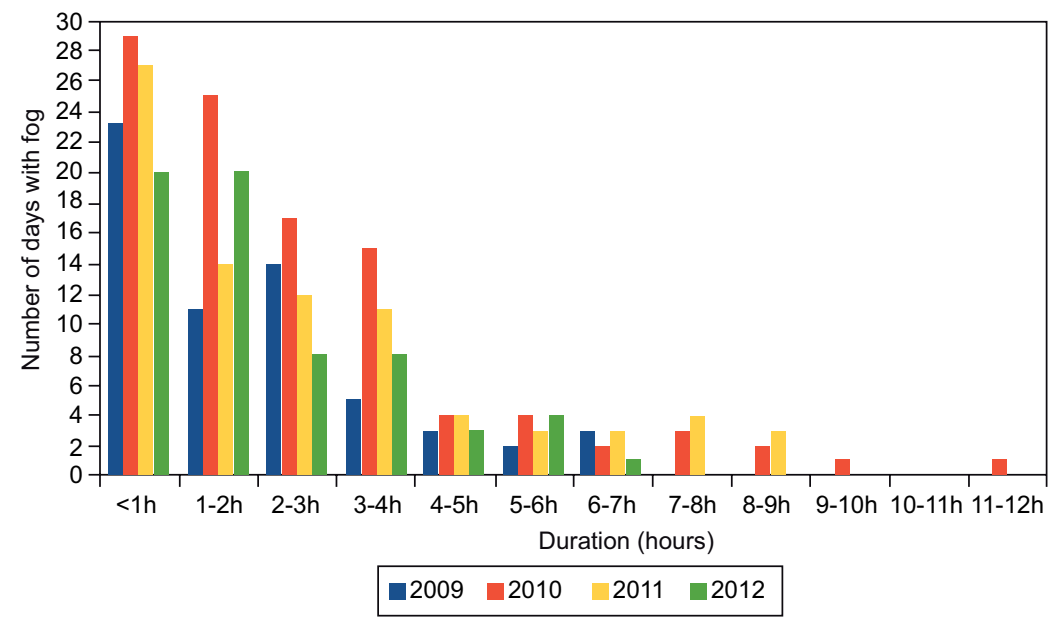

Fig. 8. Number of days with fog presence according to the year and event duration for the period January 1, 2009, to December 31, 2012. 

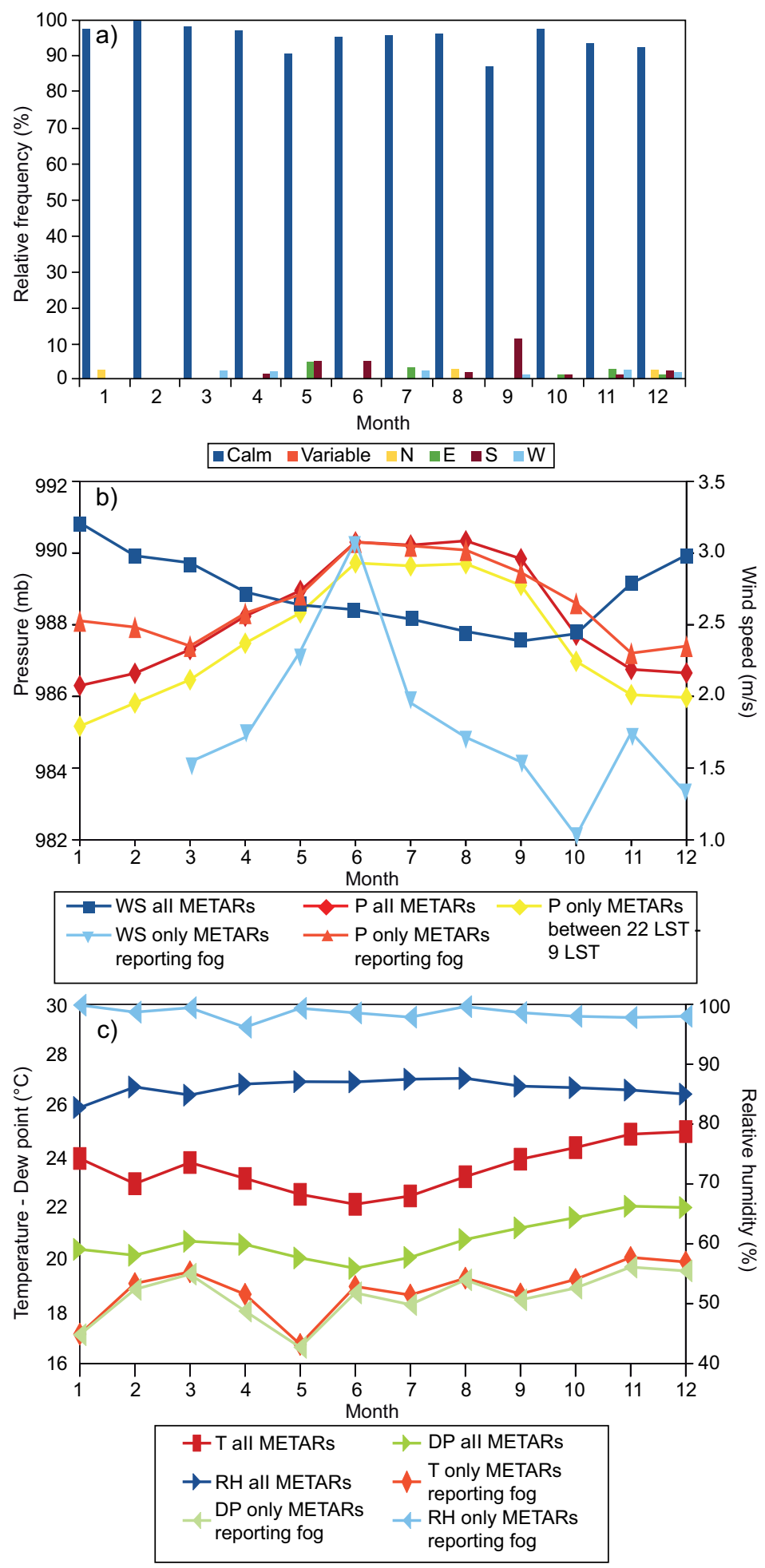

Fig. 9. Frequency of occurrence and average values of several variables according to the months of the year for METAR reports with fog registration for the period January 1, 2009, to December 31, 2012. (a), (b) and (c), as in Figure 3. Vertical axes to the left and right in (b) ([c]), also as in Figure 3. Curves in Figure 4 (for the total of METAR reports) were repeated for clarity. Monthly average pressure values calculated for all METAR reports between 22:00 and 09:00 LT (P22-9) were also included in panel (b).

of fog was consistently higher than P22-9 for all months. On average, P22-9 was 1.32 mb lower. The minimum difference occurred in September $(0.36 \mathrm{mb})$ and the maximum difference in January $(2.95 \mathrm{mb})$.

\section{Episode 1: fog after haze and fog patches} According to the surface analysis on January 24, 2009 (Fig. 10) and for the two days prior to the occurrence of the event, the Colombian territory was dominated 


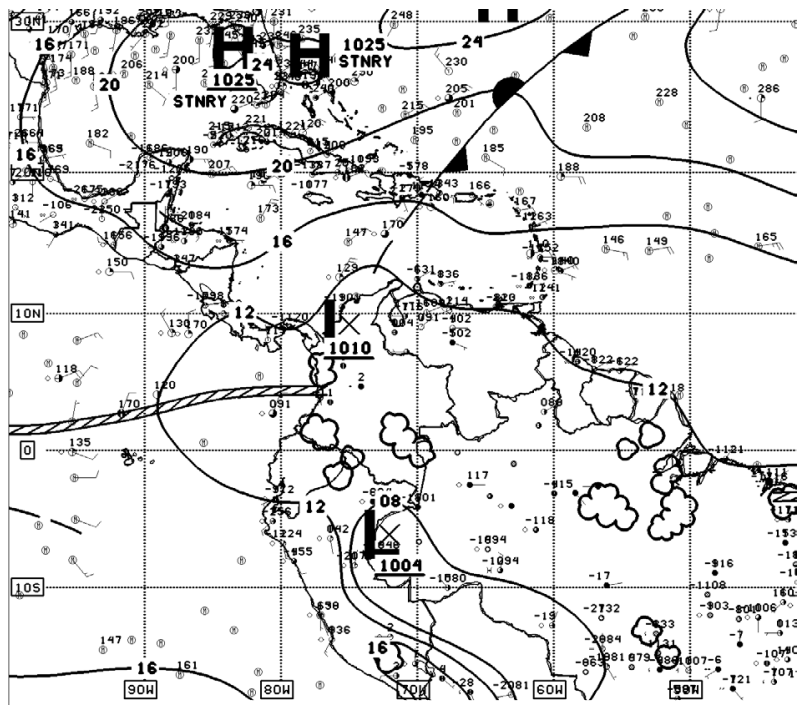

Fig. 10. Surface analysis from the Tropical Prediction Center for January 24, 2009 at 00:00 UTC (January 23, 2009 at 19:00 LT). Available at: http://archive.atmos.colostate. edu/data/misc/QPAA99/0901/09012502QPAA99.png.

a)

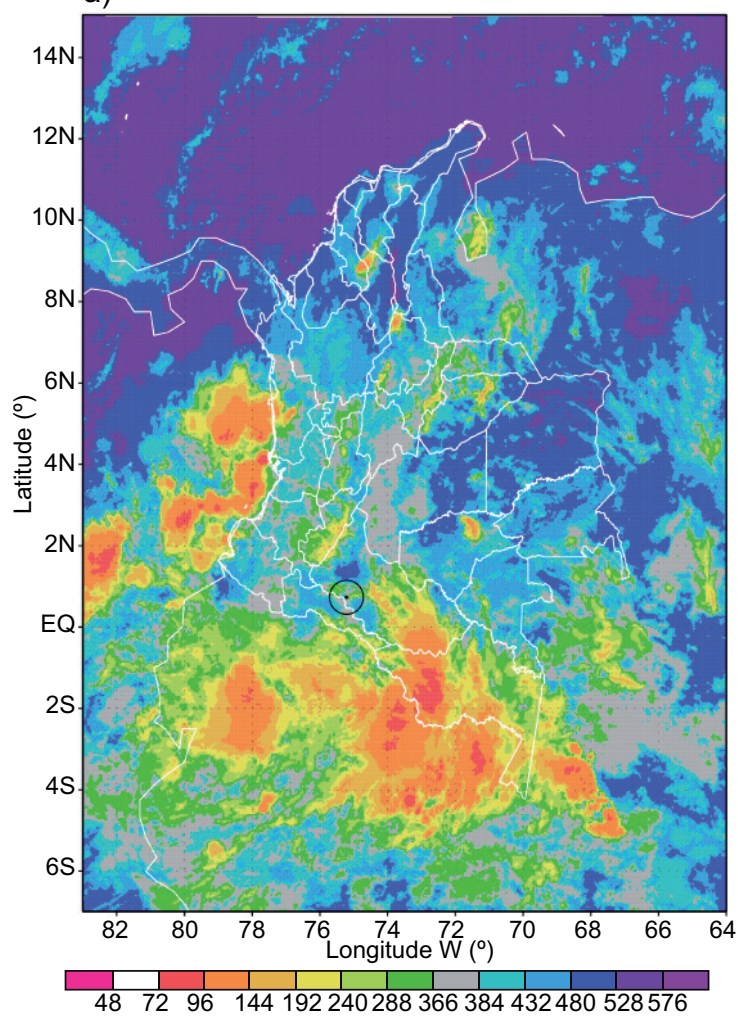

by the entry of a crest into the lower layers of the atmosphere from the northeast to the center of the Andean region, favoring the formation of stratiform-type clouds in the lower layers of the atmosphere and maintaining good weather conditions in the Colombian Caribbean and the southwest of the country. Due to the location of the ITCZ, several significant convective systems were positioned on the central and southern Colombian Pacific. To the south of the country, a low-pressure system caused convergence in the lower layers, generating vertical development of cloud formation and moderate rainfall south of the Amazon region. The Orinoco region showed little cloudiness and good weather conditions.

The analysis of cloud cover is an important factor for verifying the presence of fog. Satellite images of the area of interest (Fig. 11) indicate the type and form of cloudiness present during the occurrence of the event. The image of the infrared channel (Fig. 11a) shows stratiform-type cloudiness in the low

b)

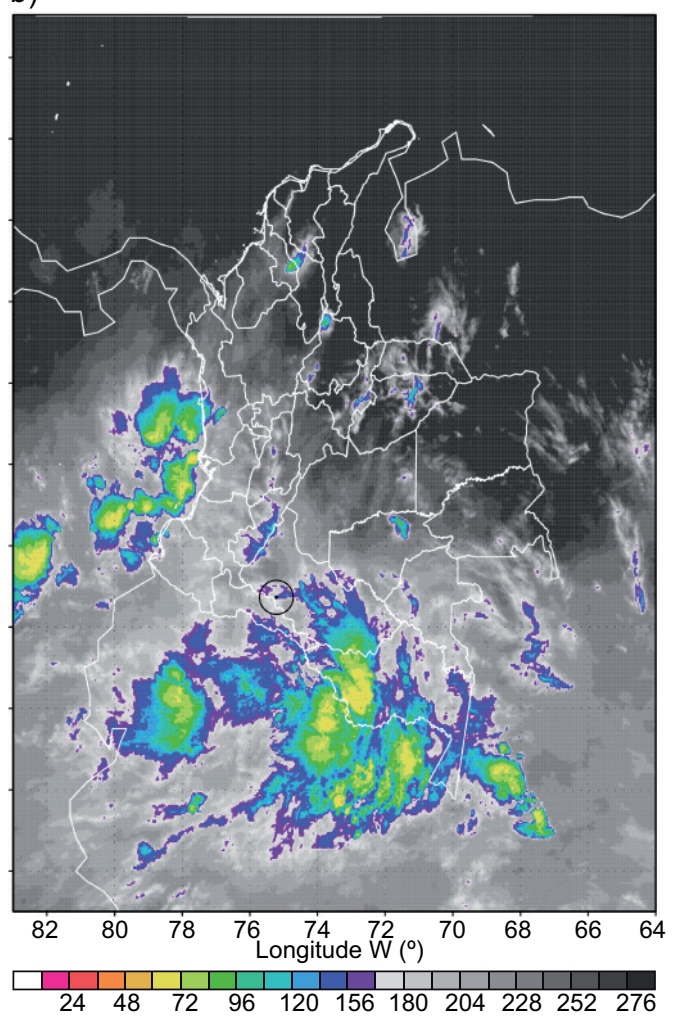

Fig. 11. Images of (a) infrared channel 4 and (b) water vapor channel taken on board the GOES-13 satellite on January 24, 2009 at 11:15 UTC (06:15 LT). The values in the images are raw counts. The images were obtained through the Comprehensive Long Array-Data Stewardship System (CLASS). Available at: http://www.nsof.class.noaa.gov/saa/products/welcome. 

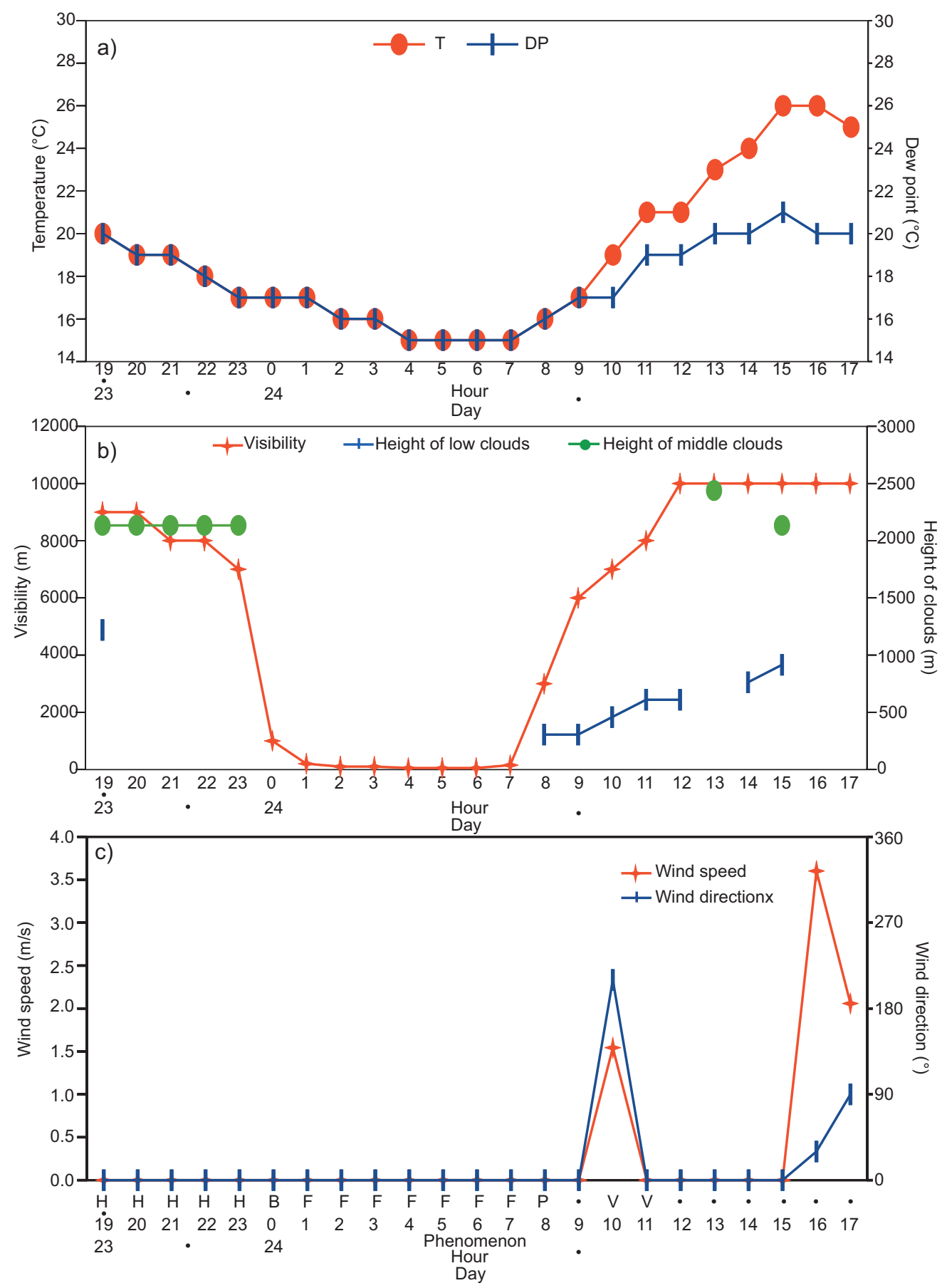

Fig. 12. Time evolution of the observed variables at the EEC aerodrome between January 23 and 24, 2009, according to METAR and SPECI reports. (a) Air temperature (T) and dew point temperature (DP). (b) Horizontal visibility and height of low and middle clouds. (c) Magnitude and direction of the wind. Only clouds that cover between 5/8 and $8 / 8$ of the sky are considered. Values on the vertical axis to the left correspond to variables in red (air temperature, horizontal wind magnitude and visibility). Values on the vertical axis to the right correspond to variables in blue or green (dew point temperature, height of middle and low clouds and wind direction). Horizontal axes in panels (a), (b) and (c) indicate the day and hour in local time (LT). The horizontal axis in panel (c) also indicates the present weather phenomenon. A point in the phenomenon line indicates the absence of any phenomenon (phenomena included were haze $[\mathrm{H}]$, patches of fog $[\mathrm{B}]$, fog $[\mathrm{F}]$, partial fog $[\mathrm{P}]$ and fog in the proximity $[\mathrm{V}])$. 

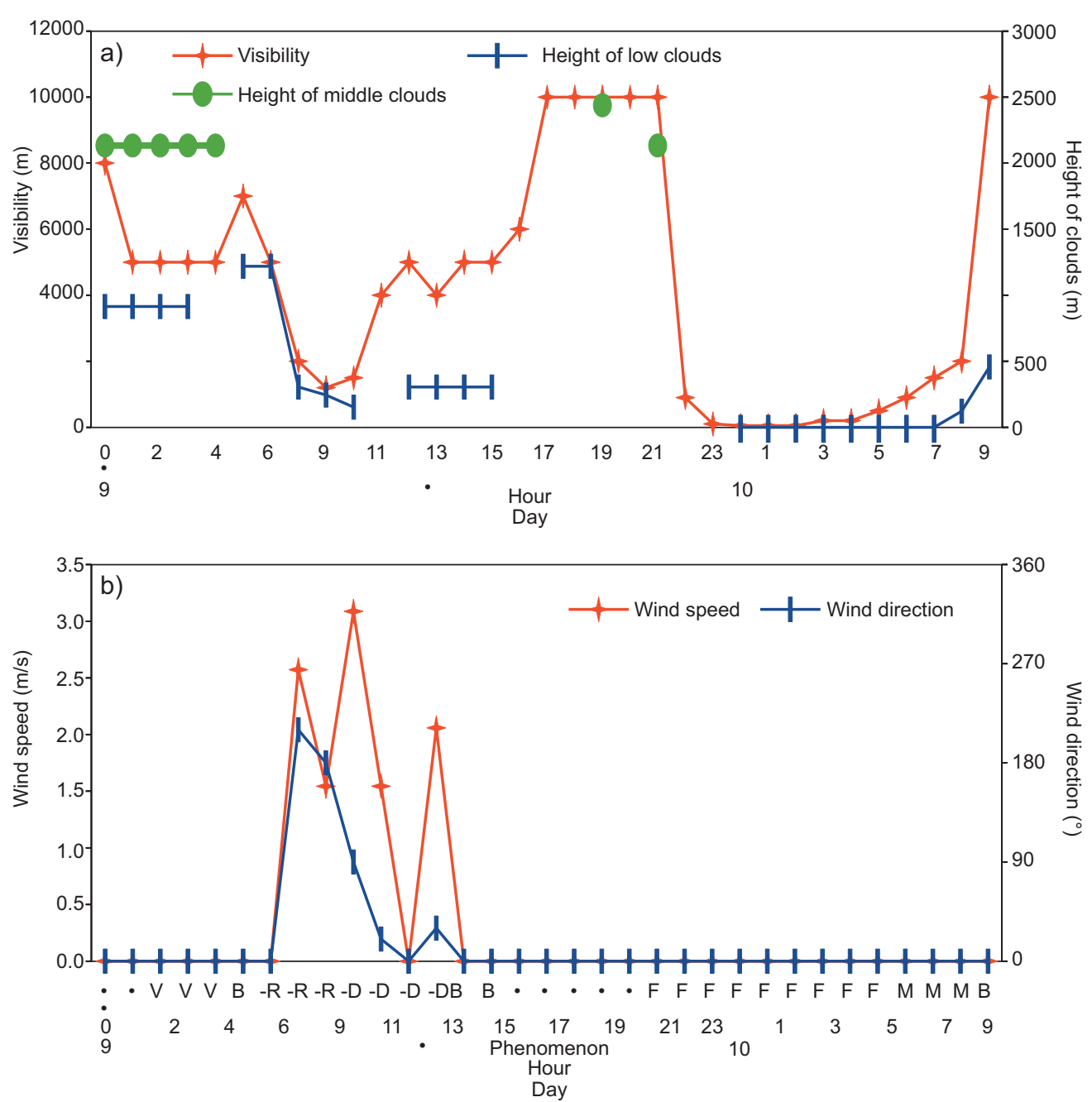

Fig. 13. Time evolution of the observed variables in the EEC between July 9 and 10, 2010 according to METAR and SPECI reports. (a) Horizontal visibility and height of low and middle clouds. (b) Magnitude and direction of the wind. Only the clouds that cover between 5/8 and $8 / 8$ of the sky are considered. Values on the vertical axes, same as in Figure 12. Horizontal axes in panels (a) and (b) indicate the day and hour in local time (LT). The horizontal axis in panel (b) also indicates the present weather phenomenon. A point in the phenomenon line indicates the absence of any phenomenon (phenomena included were fog in the proximity [V], patches of fog $[B]$, light rain $[-R]$, light drizzle $[-D]$, fog $[F]$, and mist $[M]$ ).

and middle layers above the EEC aerodrome. Figure 11b is an image of the water vapor channel, which shows the amount of moisture present in the upper layers of the atmosphere. In this image, convective cloud systems or cumuliform-type clouds are not observed in the area of interest. This confirms the presence of low stratiform-type clouds, related to the presence of fog or mist over the EEC. Figure 11a, b shows that significant mesoscale convective systems were located according to the synoptic analysis above, positioned off the central and southern Colombian Pacific coasts, on the southern Colombian Amazonia, and northern Peru.

From the analysis of satellite images and METAR and SPECI reports prior to and during the event, the following was found: the visibility went from $7000 \mathrm{~m}$ at 23:00 LT on January 23 (J23) to $200 \mathrm{~m}$ at 01:00 LT on January 24 (J24; Fig. 12b). Between 01:00 and 07:00 LT, visibility was between 50 and $200 \mathrm{~m}$, reduced by the phenomenon of fog. Between 23:00 LT on J23 and 09:00 LT on J24, calm wind was reported 


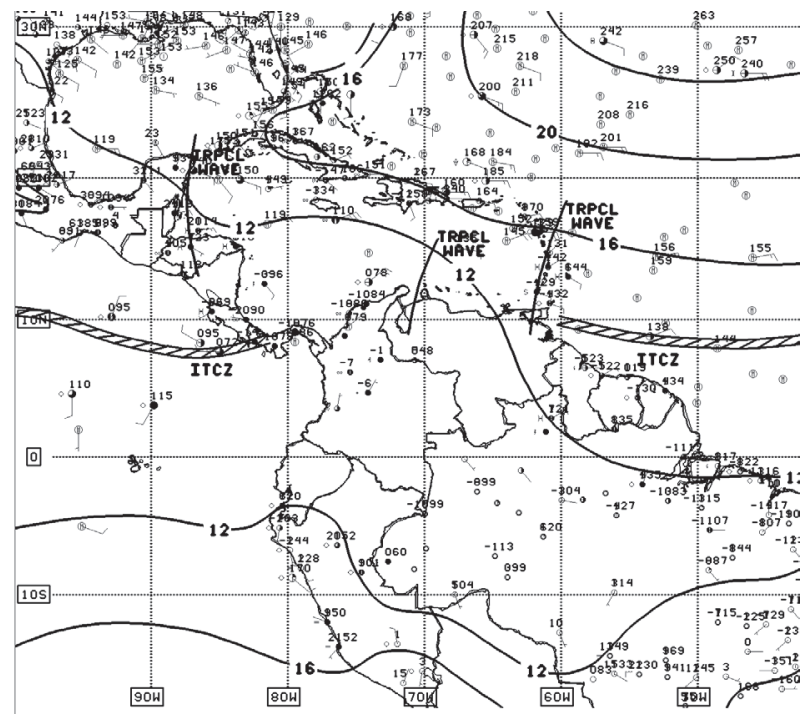

Fig. 14. Surface analysis developed by the Tropical Prediction Center for July 10, 2010, 12:00 UTC (07:00 LT). Available at: http://archive.atmos.colostate.edu/data/misc/ QPAA99/1007/10071002QPAA99.png.

(Fig. 12c). Between 23:00 LT on J23 and 1:00 LT on $\mathrm{J} 24$, air temperature was maintained at $17{ }^{\circ} \mathrm{C}$, between 02:00 and 03:00 LT it dropped to $16^{\circ} \mathrm{C}$, between 04:00 and 07:00 LT it dropped again to $15^{\circ} \mathrm{C}$, and between 08:00 and 09:00 LT it rose from 16 to $21^{\circ} \mathrm{C}$ (Fig. 12a). The dew point was equal to air temperature during the six hours of the phenomenon (01:00 to 07:00 LT), indicating that the atmosphere at low layers and at surface presented RH of $100 \%$.

METAR and SPECI reports of the days before the episode (January 20, 22 and 23; there are no reports for the 21th) informed of short-duration (1-2 h) occurrences of fog in the vicinity and mist events of short duration at similar hours than in the present case study, giving a notion of persistence in the occurrence of mist-type obscuring phenomena within the study area (not shown).

\section{Episode 2: fog after rain, drizzle and no phe- nomenon}

The METAR reports indicate that on the previous day (July 9 [J9], 2010), between 08:00 and 10:00 LT, light rain was present with an overcast sky between 305 and $153 \mathrm{~m}$ and horizontal visibility between 2000 and $1500 \mathrm{~m}$ (Fig. 13). The next four hours, from 11:00 to 14:00 LT, reports indicate slight drizzle and a cloud ceiling at $305 \mathrm{~m}$ and horizontal visibility between 4000 and $5000 \mathrm{~m}$. From 15:00 to
16:00 LT, patches of fog were present at the EEC aerodrome with horizontal visibility from 5000 to $6000 \mathrm{~m}$ and cloud ceiling at $305 \mathrm{~m}$, with broken clouds at 15:00 LT and scatter clouds at 16:00 LT. From 17:00 to 21:00 LT, there was no phenomenon, horizontal visibility was higher than $10000 \mathrm{~m}$ and the ceiling went from broken clouds at $229 \mathrm{~m}$ at 17:00 LT to no clouds between 18:00 and 21:00 LT. At 22:00 LT on J9, fog with visibility of $900 \mathrm{~m}$ was reported over the EEC aerodrome. At 23:00 LT, fog density increased and horizontal visibility decreased to $100 \mathrm{~m}$. The next METAR (00:00 LT) reported that visibility was reduced to $50 \mathrm{~m}$ the ceiling was on the surface, completely obstructing the vertical visibility and forcing the closure of the aerodrome. These bad weather conditions remained for the next three hours. From 03:00 LT, horizontal visibility began to improve from 50 to $200 \mathrm{~m}$, but the ceiling continued to restrict air operations, since it was too low and near the surface. A fully reduced vertical visibility was maintained, making it unreadable for the weather observer. These same conditions of vertical and horizontal visibility remained in the next hour (04:00 LT). At 05:00 LT, horizontal visibility increased from $200 \mathrm{~m}$ to $500 \mathrm{~m}$ and the aerodrome continued under instrument flight operation. At 06:00 LT, horizontal visibility increased from 500 to $900 \mathrm{~m}$, while vertical visibility remained fully reduced. At 07:00 LT, the intensity of the phenomenon decreased and evolved from fog to mist (BR), improving the horizontal visibility to $1500 \mathrm{~m}$, but vertical visibility continued to be reduced to its maximum. The METAR at 08:00 LT reported calm wind, horizontal visibility of $2000 \mathrm{~m}$ in the presence of mist, and an overcast ceiling reduced to $122 \mathrm{~m}$. The weather suddenly improved at 09:00 LT and horizontal visibility became greater than $10 \mathrm{~km}$, the wind continued calm, and fog patches and fragmented clouds at $457 \mathrm{~m}$ were reported. For this episode, and also for episode 3 , there is no data of temperature or dew point. This is because July 2010 and November 2011 were two of the months in which these variables were not measured, due to failures in the automatic weather station installed at the EEC aerodrome (SIMFAC, 2009).

The synoptic conditions show that the ITCZ was located between 9 and $10^{\circ} \mathrm{N}$ (see Fig. 14) favoring deep convection over the western Colombian Caribbean, entering Colombian territory near the Gulf of 
a)

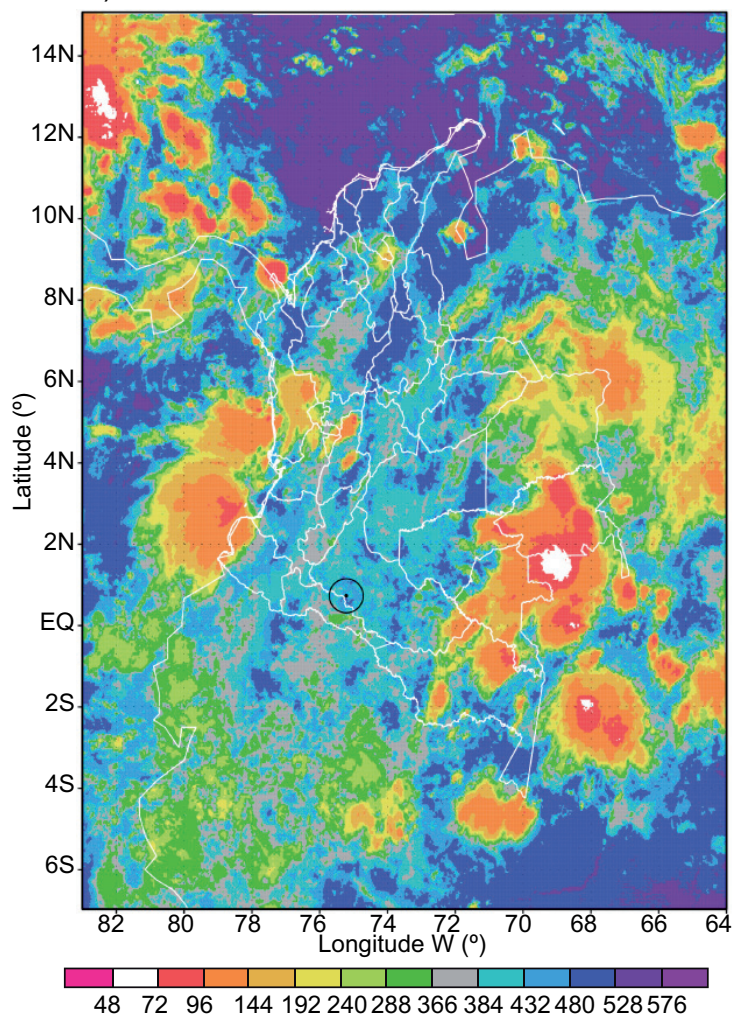

b)

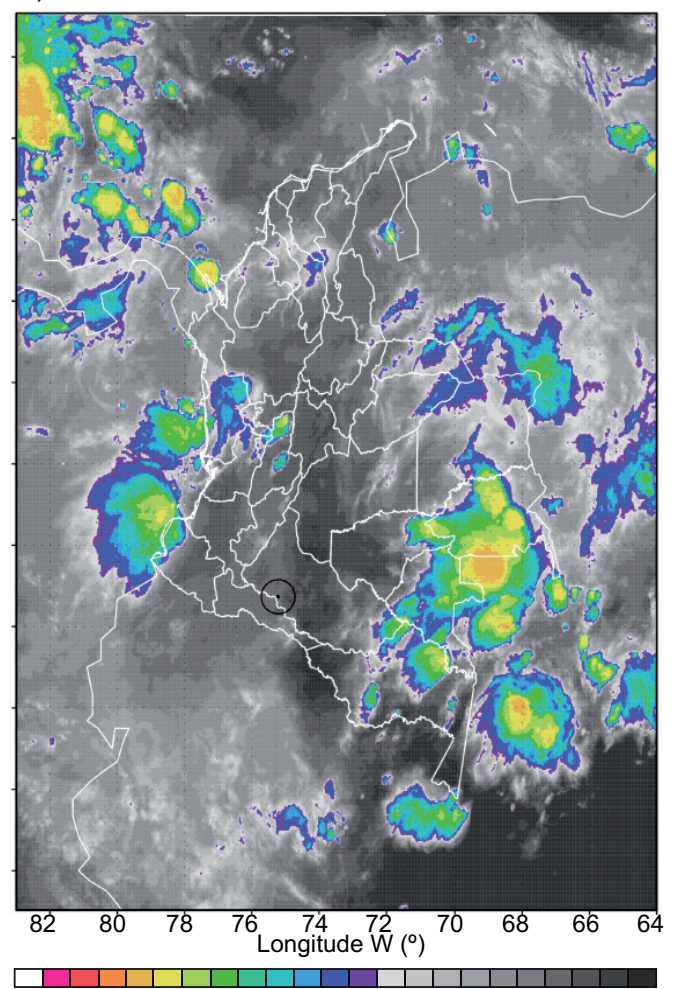

Fig. 15. Images of (a) infrared channel 4 and (b) water vapor channel taken on board the GOES-13 satellite on July 10, 2010 at 12:15 UTC (07:15 LT). Values in the images are raw counts. The images were obtained through the Comprehensive Large Array-Data Stewardship System (CLASS). Available at: http://www.nsof.class.noaa.gov/saa/products/welcome.

Urabá and interacting favorably with a tropical wave that moved from east to west on the north, to possibly generate cyclonic systems near the surface that increase low cloudiness and precipitation, as shown in the synoptic reports generated by airports in Santa Marta, Barranquilla and Cartagena. The center of the Colombian Caribbean had good weather conditions with low stratiform clouds. On the archipelago of San Andrés and Providencia, there were cumulus clouds in the middle layers but these did not favor the presence of rain. As shown in Figure 14, the lack of synoptic information for southwestern Colombia hinders further analysis.

The infrared image at 9:15 UTC (04:15 LT) on July 10, 2010 (Fig. 15a) shows that over the EEC aerodrome there were low stratiform clouds associated with the presence of mist. The water vapor image in Figure 15b confirms that in the study area there were no clouds of vertical development that inhibited the formation of fog or mist, and also that significant mesoscale convective systems were located according to the synoptic analysis above, off the Colombian Pacific coast, over the Orinoco and south of Amazon regions, which favors rainfall over these areas.

The analysis of a thermodynamic profile does address the lack of observed surface temperature. The profile shows at what levels the saturation of the atmosphere (air temperature $=$ dew point temperature) is $100 \%$. The radio sounding performed the day of the study (Fig. 16) indicates high moisture contents in the lower layers (surface) since air temperature (right) equals the dew point temperature (left), so the presence of fog in EEC aerodrome is supported. Moreover, calm wind was recorded at the surface. Similar conditions of high moisture content can be seen in the middle layers of the atmosphere, where a dense layer of clouds could be observed in satellite images (Fig. 15). 


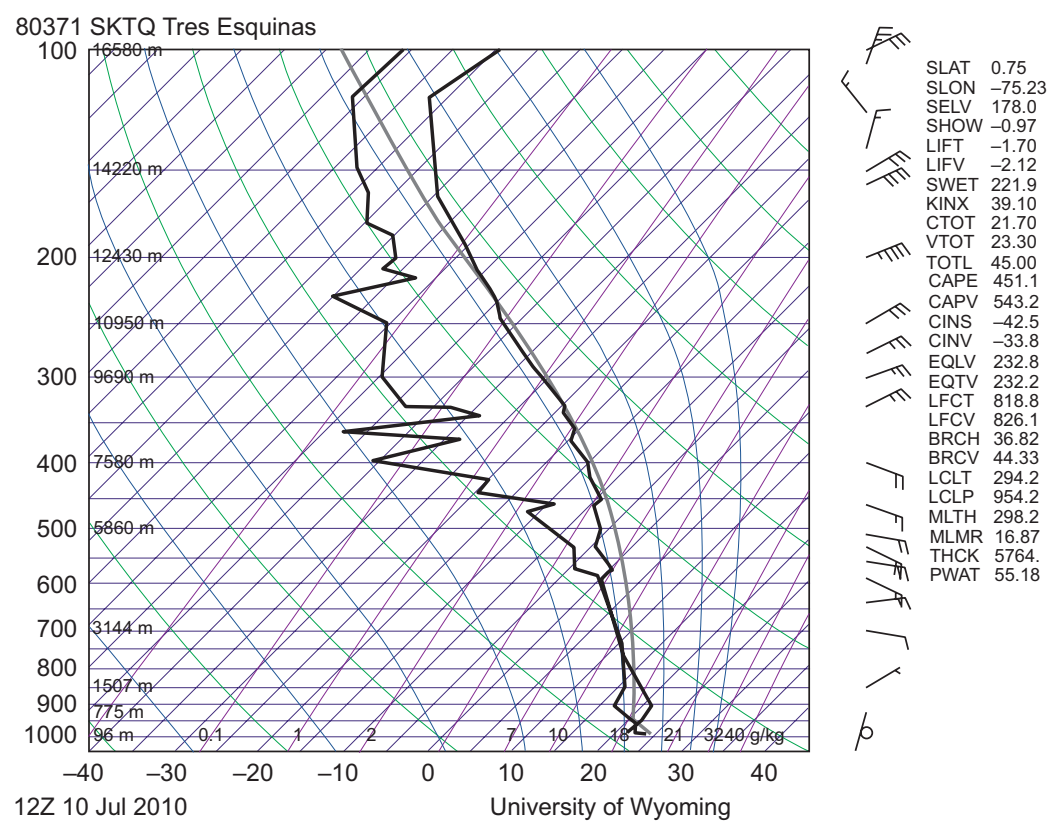

Fig. 16. Radio sounding made in the EEC aerodrome on July 10, 2010 at 12:00 UTC (07:00 LT) by the Colombian Air Force (FAC). Available at: http://weather.uwyo.edu/upperair/sounding.html.

\section{Episode 3: fog after drizzle, no phenomenon and patches of fog}

Figure $17 \mathrm{a}, \mathrm{b}$ shows that there was drizzle on November 24, 2011 from 11:00 to 13:00 LT. After that, seven hours followed (14:00-21:00 LT) with favorable weather: mild or calm wind, visibility greater than $10000 \mathrm{~m}$, average cloudiness dispersed and no phenomenon. From 22:00 to 23:00 LT, fog in the vicinity of the EEC aerodrome (8000-16 $000 \mathrm{~m}$ away from a reference point at the EEC), wind calm, visibility at $8000 \mathrm{~m}$ and scattered clouds (cloud cover between $3 / 8$ and $4 / 8$ of the sky) between $2133 \mathrm{~m}$ and $2438 \mathrm{~m}$ were reported. Between 00:00 and 01:00 LT reports announced fair weather conditions, which deteriorated from 02:00 LT. At 02:00 and 03:00 LT fog patches were reported and visibility was reduced from $9000 \mathrm{~m}$ to $3000 \mathrm{~m}$. At 04:00 LT calm wind at the EEC aerodrome was reported, visibility was reduced to $50 \mathrm{~m}$ and the cloud ceiling was found on the surface, forming fog for four straight hours and forcing the aerodrome closure due to adverse weather conditions. In those four hours, fog remained with the same calm wind conditions and cloud ceiling on the surface affecting vertical visibility.
Horizontal visibility increased from 50 to $100 \mathrm{~m}$ at 06:00 LT, however the aerodrome remained closed. The fog phenomenon persisted and visibility continued to be reduced to $200 \mathrm{~m}$ as reported in the METAR at 07:00 LT. At 08:00 LT, visibility was $800 \mathrm{~m}$ and fog remained, restricting operations. At 08:30 LT a SPECI report was generated as visibility improved from 800 to $5000 \mathrm{~m}$, just as the ceiling ascended to $610 \mathrm{~m}$ with fragmented clouds. The fog over the EEC aerodrome was replaced by patches of fog recorded in the 08:30 LT SPECI report and the 09:00 LT METAR report. Fog patches dissipated and weather conditions improved considerably at 10:00 LT, when northeasterly wind $\left(20^{\circ}\right)$ with an intensity of $2.6 \mathrm{~ms}^{-1}$, greater visibility to $10000 \mathrm{~m}$ and few low clouds at $610 \mathrm{~m}$ were reported.

This case study is interesting because several foggy events (VCFG, BR, BCFG, FG, MIFG) occurred $36 \mathrm{~h}$ before the start and $24 \mathrm{~h}$ after the completion of the time period considered in Figure 17 (not shown). When synoptic analysis is performed, it is observed that no synoptic phenomenon occurred which could affect synoptic-scale weather conditions on the southwest of the country. In the Southern Hemisphere there were no significant events (Fig. 18). The ITCZ was located at the north of Colombia, thus it was 

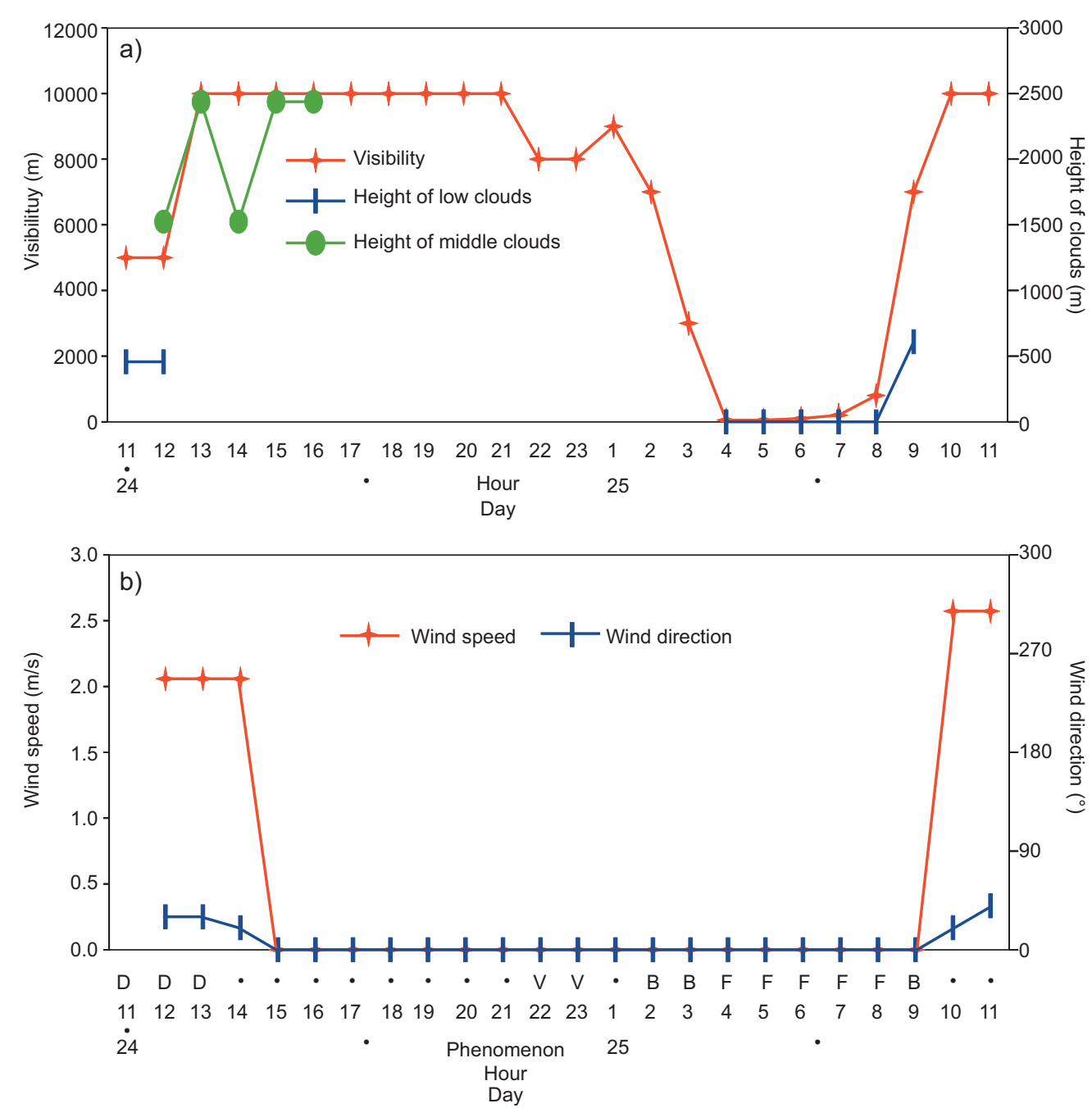

Fig. 17. Time evolution of the observed variables in the EEC between November 24 and 25, 2011 according to METAR and SPECI reports. (a) Horizontal visibility and height of low and middle clouds. (b) Magnitude and direction of the wind. Only the clouds that cover between 5/8 and 8/8 of the sky are considered. Values on the vertical axes, same as in Figure 12. Horizontal axes in panels (a) and (b) indicate the day and hour in local time (LT). The horizontal axis in panel (b) also indicates the present weather phenomenon. A point in the phenomenon line indicates the absence of any phenomenon (phenomena included were drizzle [D], fog in the proximity[V], patches of fog $[\mathrm{B}]$, and fog $[\mathrm{F}])$.

not necessary for it to be positioned near the EEC aerodrome to favor the occurrence of fog or mist. A trough front is seen near $10^{\circ} \mathrm{N}$ and $53^{\circ} \mathrm{W}$ poised to enter the continent, which in the next two or three days could affect the conditions east of the country with the transport of moisture and triggering a deep convection in that region.

The weakened ITCZ was located about $10^{\circ} \mathrm{N}$ on the west side of Colombia triggering convection on the central and eastern Colombian Caribbean Sea
(Fig 19a), favoring rainfall over much of the northern coast and generating convective systems over the departments of Norte de Santander, César and Bolívar. The clouds of vertical development are most easily seen in Figure 19b, which shows the contents of moisture in the upper layers of the atmosphere. In southern Guainía and northeastern Vaupés, low and middle clouds, which generated moderate rains in the sector, can be seen. The rest of the country showed a few clouds of stratiform type and some orographic 


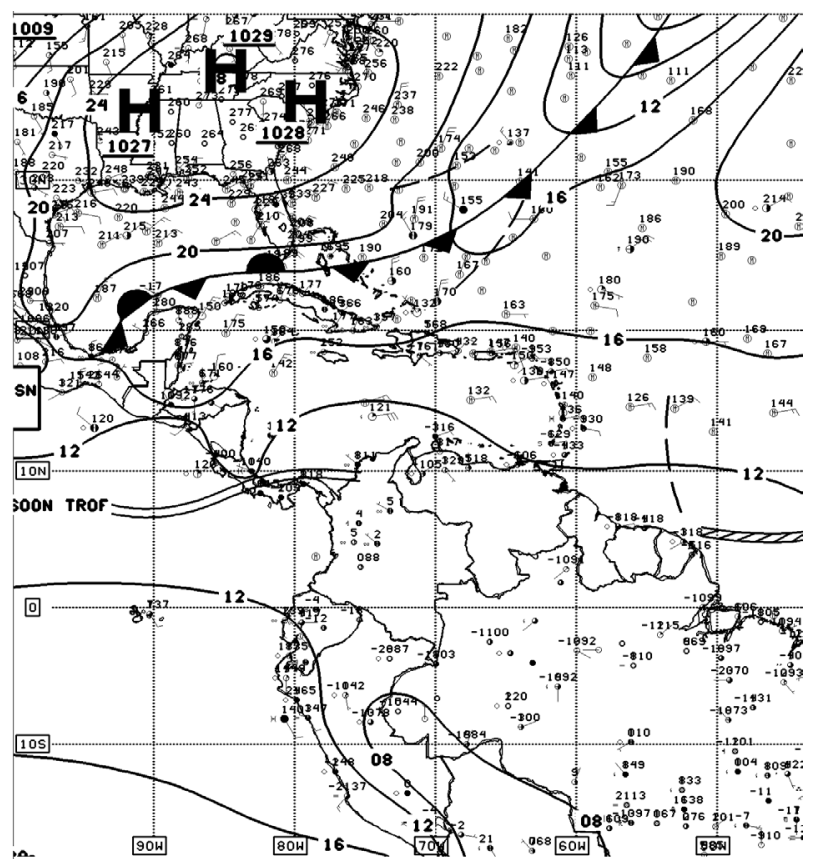

Fig. 18. Surface analysis carried out by the Tropical Prediction Center on November 25, 2011 at 00:00 UTC (November 24, 2011, 19:00 LT). Available at: http://archive.atmos.colostate.edu/data/misc/ QPAA99/1111/11112502QPAA99.png.

a)

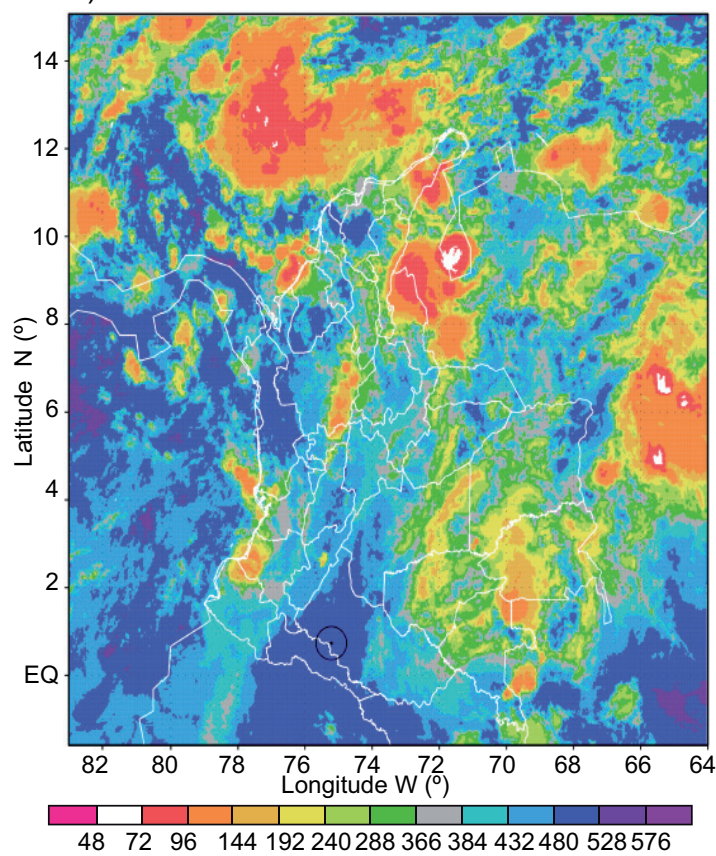

clouds over the Cordillera Central (Central Mountain Range). Above the department of Caquetá (where the EEC aerodrome is located) there are a few low clouds of stratiform type. From 20:15 LT on November 24 to 08:00 LT on November 25, at which time the presence of fog at the EEC aerodrome was last reported, these conditions remained constant. Skies with few clouds favors radiative cooling and according to METAR reports, calm winds prevailed during the entire event, which increased the likelihood of fog and mist.

The radio sounding held on November 25 at 12:00 UTC (07:00 LT) at the EEC aerodrome (Fig. 20) shows there was saturation in the lower layers of the atmosphere resulting in the presence of fog or haze on the surface. Moreover, in the middle and upper layers of the atmosphere, isolines of air temperature and dew point temperature are separated, indicating no significant cloud cover for the development of air operations at those heights.

\section{Conclusions}

This study analyzed information from METAR reports to determine the characteristics of fog events at the EEC aerodrome, i.e., when visibility is $1 \mathrm{~km}$

b)

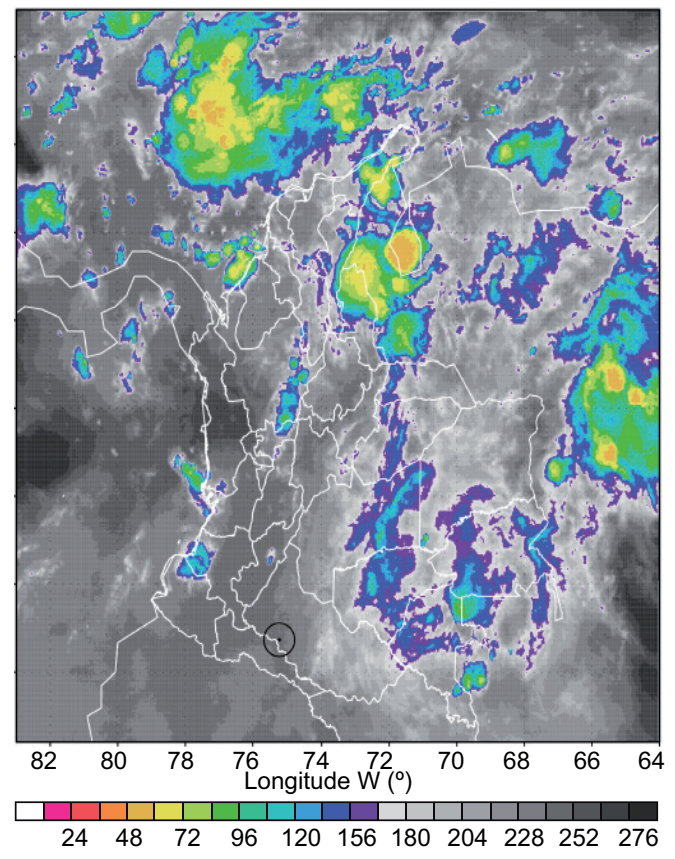

Fig. 19. Images of (a) infrared channel 4 and (b) water vapor channel taken aboard the GOES-13 satellite on November 25, 2011 at 09:15 UTC (04:15 LT). The values in the images are raw counts. The images were obtained from the Comprehensive Large Array-data Stewardship System (CLASS). Available at: http://www.nsof.class.noaa.gov/saa/products/welcome. 


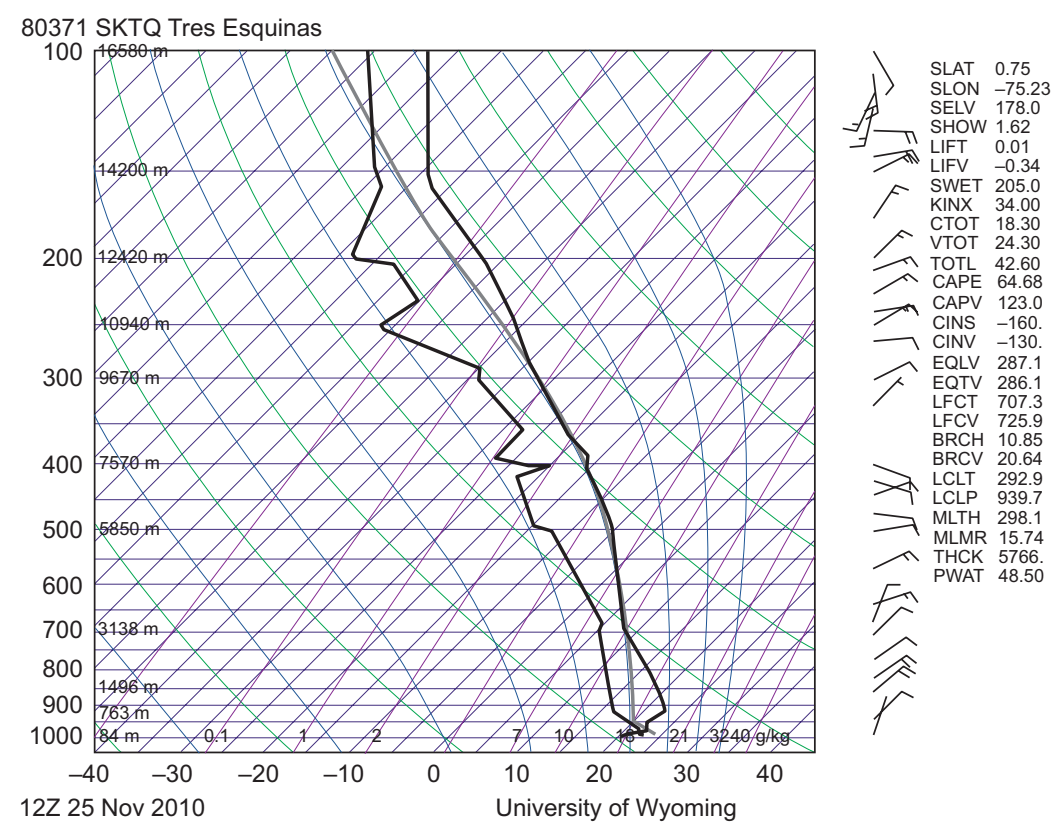

Fig. 20. Radio sounding made in the EEC aerodrome on November 25, 2011 at 12:00 UTC (07:00 LT) by the Colombian Air Force (FAC). Available at: http://weather.uwyo.edu/upperair/sounding.html.

or less, $\mathrm{RH}$ is above $90 \%$ and a human observer reports the presence of fog as a weather phenomena. Fog is a frequent meteorological phenomenon in the EEC aerodrome, on average on in every five days during the study period had at least one report of fog. Fog is the main cause of airport closure due to weather conditions, accounting for $45.26 \%$ of the total hours of closure. The high percentage of episodes of fog in calm winds (95\%) indicate that fog at the EEC aerodrome is basically of the radiative type, and episodes take place primarily between 22:00 and 08:00 LT (03:00 and 13:00 UTC). Fog appeared in every month of the year. The longest event lasted between 11 and 12 hours. Monthly averages of pressure obtained only with METAR reports that recorded fog are on average 1.32 $\mathrm{mb}$ higher than the monthly averages calculated with all METAR reports for the hours when fog is most likely to occur at the EEC aerodrome, i.e., between 22:00 LT and 09:00 LT.

The analysis of the synoptic scale by using charts of surface and satellite images allowed us to determine how the circulation and dynamics of the North Atlantic Anticyclone and the ITCZ regulate the formation of fog or mist over the EEC aerodrome. When the anticyclone is farthest from Colombia and the
ITCZ is located to the north subsidence is generated in lower and middle levels by inhibiting convection over the northwestern part of the Colombian Amazonia and favoring the occurrence of fog or mist in the area. Subsidence in low and medium levels that inhibits convection over the northwestern part of the Colombian Amazonia, favoring the occurrence of fog or mist in the area, is also related to convective activity in the departments of Guainía, Vaupés and Guaviare. These conditions together with few clouds and calm winds favor radiative cooling, increasing the likelihood of fog and mist.

\section{References}

Aguilar-González A. I. and G. E. León-Aristizábal, 2004. Aproximación a un modelo de pronóstico para niebla de radiación en Rionegro-Antioquia. Meteorología Colombiana 8, 89-97. Available at: http://ciencias.bogota.unal.edu.co/fileadmin/content/geociencias/revista_meteorologia_colombiana/nu mero08/08_11.pdf.

Baars H., A. Ansmann, D. Althausen, R. Engelmann, B. Heese, D. Muller, P. Artaxo, M. Paixao, T. Pauliquevis and R. Souza, 2012. Aerosol profiling with lidar in the Amazon Basin during the wet and dry season. J. Geophys. Res.-Atmos. 117, doi:10.1029/ 2012JD018338. 
Goldberg R., F. Tisnado and R. Scofield, 1988. Characteristics of extreme rainfall events in northwestern Peru during the 1982-1983 El Niño period. J. Geophys. Res. 92, 14225-14241.

De Araújo A. C., 2009. Spatial variation of $\mathrm{CO}_{2}$ fluxes and lateral transport in an area of terra firme forest in Central Amazonia. PhD thesis, Vrije Universiteit, Amsterdam.

Eugster W., 2008. Fog research. Die Erde 139, 1-10.

Gultepe I., R. Tardif, S. C. Michaelides, J. Cermak, A. Bott, J. Bendix et al., 2007. Fog research: A review of past achievements and future perspectives. Pure Appl. Geophys. 164, 1121-1159.

Horel J. D. and A. Cornejo-Garrido. 1986. Convection along the coast of northern Peru 1983: Spatial and temporal variations of clouds and rainfall. Mon. Weather Rev. 114, 2091-2105.

IDEAM, 2005. Atlas climatológico de Colombia. Instituto de Hidrología, Meteorología y Estudios Ambientales. Available at: http://documentacion.ideam.gov.co/ openbiblio/bvirtual/019711/019711.htm.

Jiménez-Sánchez J. G. and J. A. Zea-Mazo, 2005. Caracterización de la bruma, llovizna y lluvia como fenómenos meteorológicos adversos a la operación bajo reglas de vuelo visual (VRF) en el aeródromo “Germán Olano”. Meteorología Colombiana 9, 15-22. Available at: http://ciencias.bogota.unal.edu.co/filead$\mathrm{min} /$ content/geociencias/revista_meteorologia_colombiana/nu mero09/09_03.pdf.

Kamara S. I., 1989. Diurnal and seasonal variations of fog over Sierra Leone. Singapore J. Trop. Geo. 10, 160-169, doi:10.1111/j.1467-9493.1989.tb00012.x.

León-Aristizábal G. E., J. A. Zea-Mazo and J. A. Eslava-Ramírez, 2000. Circulación general del trópico y la zona de confluencia intertropical en Colombia. Meteorología Colombiana 1, 31-38. Available at: http:/ciencias.bogota.unal.edu.co/fileadmin/content/ geociencias/revista_meteorologia_colombiana/nu mero01/01_05.pdf.

Liu W. J., P. Y. Wang, W. Y. Liu, J. T. Li and P. J. Li, 2008. The importance of radiation fog in the tropical seasonal rain forest of Xishuangbanna, south-west China. $\mathrm{Hy}$ drol. Res. 39, 79-87, doi:10.2166/nh.2008.031.
Martínez R., D. Ruiz, M. Andrade, L. Blacutt, D. Pabón, E. Jaimes, G. León, M. Villacís, J. Quintana, E. Montealegre and C. Euscátegui, 2011. Synthesis of the climate of the tropical Andes. In: Climate change and biodiversity in the tropical Andes (S. K. Herzog, R. Martínez, P. M. Jørgensen and H. Tiessen, Eds.). McArthur Foundation-IAI-SCOPE, 97-109.

Meiyappan P. and A. K. Jain, 2012. Three distinct global estimates of historical land-cover change and land-use conversions for over 200 years. Front. Earth Sci. 6, 122-139, doi:10.1007/s11707-0120314-2.

Obregón A., C. Gehrig-Downie, S. R. Gradstein, R. Rollenbeck and J. Bendix, 2011. Canopy level fog occurrence in a tropical lowland forest of French Guiana as a prerequisite for high epiphyte diversity. Agr. Forest. Meteorol. 151, 290-300.

Obregón A., C. Gehrig-Downie, S. R. Gradstein and J. Bendix, 2014. The potential distribution of tropical lowland cloud forest as revealed by a novel MODIS-based fog/low stratus night-time detection scheme. Remote Sens. Environ. 155, 312-324.

Poveda G., P. R. Waylen and R. S. Pulwarty, 2006. Annual and inter-annual variability of the present climate in northern South America and southern Mesoamerica. Palaeogeogr. Palaeocl. 234, 3-27.

Richter M., E. Beck, R. Rollenbeck and J. Bendix, 2013. The study area. In: Ecosystem services, biodiversity and environmental change in a tropical mountain ecosystem of South Ecuador ( and, . Springer. Berlin, Heidelberg, New York, 3-18.

SIATAC, 2013. Mapa de coberturas de la tierra periodo 2012. Sistema de Información Ambiental Territorial de la Amazonia Colombiana-Instituto Amazónico de Investigaciones Científicas SINCHI. Available at: http://geosemantica.siatac.co/collections/ map_viewer.aspx?id=073f06a4-59b0-47f7-bdaf239482a $82 \mathrm{e} 52 \& \mathrm{c}=1$.

SIMFAC, 2009. Reporte interno del Sistema de información Meteorológico de la Fuerza Aérea Colombiana año 2009.

Tardif R. and Rasmussen R. M., 2007. Event-based climatology and typology of fog in the New York City region. J. Appl. Meteorol. Clim. 46, 1141-1168. 